\title{
COOPERAÇÃO PENAL NA UNIÃO EUROPÉIA
}

COOPERATION IN CRIMINAL MATTERS IN THE EUROPEAN UNION

Talitha Viegas Borges

\begin{abstract}
Resumo:
Este artigo tem por objetivo apresentar um quadro geral sobre a cooperação penal na União Européia que hoje se insere dentro de uma idéia mais ampla de um espaço de liberdade, segurança e justiça. A evolução histórica do tratamento da matéria é traçada para explicar como se chegou ao estágio atual. Havia inicialmente - por parte dos Estados-Membros uma natural reticência em discutir questões penais no âmbito internacional. Hoje, entretanto, se verifica que muitas questões sobre cooperação penal são decididas pela própria União Européia. Além do estudo desses antecedentes históricos, o presente artigo faz uma análise das principais mudanças introduzidas pelo Tratado de Lisboa, que entrou em vigor em $1^{\circ}$ de Dezembro de 2009; bem como dos atuais instrumentos de que a União Européia dispõe para implementar a cooperação penal. O Tratado de Lisboa além de atribuir personalidade jurídica à União Européia também lhe conferiu atributos supranacionais. De forma que, algumas decisões sobre cooperação penal passam a sujeitar-se à aprovação majoritária. Portanto, em regra, o consenso deixa de ser necessário para aprovação de medidas sobre cooperação penal. Além da mudança sobre o processo decisório, com o Tratado de Lisboa, a margem de atuação da União Européia foi consideravelmente aumentada no que diz respeito à cooperação penal. Essa atuação, entretanto, continua a ter limites, os quais são estabelecidos de acordo com os objetivos enunciados nos tratados constitutivos da União Européia e também de acordo com a atuação dos Estados-Membros.
\end{abstract}

Palavras chave: Cooperação penal. União Européia. Supranacionalidade. Tratado de Lisboa.

\begin{abstract}
:
This article attempts to present a general framework on the cooperation in criminal matters within the European Union. Currently, this cooperation is embedded within a broader idea of a space of freedom, security and justice. The following work first traces the historical background in order explain how the cooperation on criminal matters reached its current stage. The discussion of this cooperation at an international level suffered from an initial reluctance from the Member States. Today, however, the EU obtained its own competence to decide on cooperation in criminal matters. This article further analyses the major changes introduced by the Lisbon Treaty, which entered into force on December $1^{\text {st }}$ of 2009. It also examines the instruments available in order for the EU to implement the cooperation among its Member States regarding criminal matters. Not only did the Treaty of Lisbon confer a legal personality to the EU, it also conceded the EU supranational attributes, so that decisions on cooperation in criminal matters are now subject to majority approval. Therefore, as a rule, consensus is no longer necessary for the adoption of measures on cooperation in criminal matters. In addition, the Lisbon Treaty broadened the
\end{abstract}

\footnotetext{
* Bacharel em Direito pela Faculdade de Direito da Universidade de São Paulo.
} 
scope of work of the European Union. It's actions; however, are still limited by the objectives stated in the founding treaties of the European Union and must also take into account the Member States' scope of action.

keywords: Cooperation in criminal matters. European Union. Supranationality. Treaty of Lisbon.

Introdução

O presente artigo tem por objetivo analisar a forma de cooperação penal que se estabeleceu na União Européia e as mudanças que o Tratado de Lisboa introduziu sobre o tema.

Inicialmente será apresentado o conceito de cooperação penal internacional. Em seguida apresentar-se-á um panorama geral sobre como a matéria foi introduzida e tratada na União Européia pelos sucessivos tratados constitutivos. Essa análise permitirá a correta compreensão de como se chegou ao modelo atual de cooperação penal europeu. Serão então analisadas as novas dimensões que o tema adquiriu com o Tratado de Lisboa e por fim serão levantadas algumas reflexões sobre a competência do ente supranacional.

Será dada ênfase ao processo de comunitarização da competência em assuntos penais, que possui uma forte tendência expansionista, mais que ao aspecto processual penal. Analisar-se-á, sobretudo a relação que os Estados-Membros passam a ter com a União Européia e a dinâmica dos órgãos comunitários responsáveis por implementar as competências supranacionais.

O tema é bastante atual, uma vez que o quadro normativo e institucional da cooperação penal européia encontra-se ainda em processo de desenvolvïmento. Existe, por exemplo, um projeto de normatização que visa, através de uma diretiva européia, garantir que um cidadão ao ser preso por suspeita de um crime deverá ser informado de seus direitos. Assim, ele deve entender quais são seus direitos, em qualquer que seja dos Estados-Membros. ${ }^{1}$

Através de exemplos como esse, buscar-se-á ao longo do trabalho demonstrar como a cooperação de desenvolve na prática e o que pode ou não ser admitido na atuação da União.

Disponível em: <http://ec.europa.eu/deutschland/pdf/eu_nachrichten/eu-nachr.27_2010web.pdf $>$. Acesso em: 06 set. 2010. 
Do conceito de cooperação penal internacional

Objeto

A internacionalização de assuntos antes pertencentes unicamente ao âmbito interno dos estados possui uma forte tendência expansiva, abrangendo também ao direito penal. Para levar esse tema à discussão na esfera internacional foi necessário um longo processo de aproximação dos estados em outras áreas. A cooperação internacional teve início e intensificou-se, sobretudo na esfera comercial, passando então paulatinamente a abranger outros assuntos. Essa evolução na abrangência de temas objetos de cooperação, resulta da vontade de promover uma melhor inserção internacional de cada estado.

Mas, se por um lado a cooperação em questões comerciais, ou mesmo trabalhistas é evidente e desejada pela maioria dos estados, o mesmo não ocorre com questões penais. A resistência em se estabelecer a cooperação penal é compreensível, uma vez que se trata de um assunto extremamente sensível aos interesses democráticos. $\mathrm{O}$ direito penal, fortemente influenciado por elementos culturais de cada região, é entendido como ultima ratio e em razão disso os procedimentos e regras aplicáveis a essa área do direito são muito menos flexíveis do que os aplicados em outras áreas - o que muitas vezes dificulta uma maior interação.

Não obstante essas características, a crescente preocupação com o terrorismo, o narcotráfico e a lavagem de dinheiro influenciou fortemente a inclusão da cooperação penal na agenda internacional. A necessidade fez surgir diferentes métodos de cooperação penal, dentre os quais aquele adotado pela a União Européia.

É preciso esclarecer que é possível optar por inúmeros caminhos para a implementação da cooperação penal, levando-se em conta os principais desafios a serem equacionados. Por isso existem diversas modalidades de cooperação: policial ou judicial, tradicional ou inovadora e bilateral ou multilateral. A cooperação penal judicial se dá na fase processual e a policial na fase de investigação. A primeira é um importante instrumento de melhora qualitativa na prestação jurisdicional. Nela o fluxo de informações se dá já na fase instrutória do processo penal, enquanto que na cooperação policial ela ocorre na fase investigativa. Essa distinção é importante na medida em que diferem os pressupostos e objetivos de cada uma. Tanto a cooperação policial, quanto a cooperação judicial, estão atualmente presentes na União Européia.

Uma segunda modalidade de cooperação penal se refere a mecanismos tradicionais ou inovadores. Dentre os mecanismos tradicionais, encontra-se a carta 
rogatória, mediante a qual autoridades estrangeiras solicitam diligências por autoridades do país requerido. ${ }^{2}$ Também a homologação de sentença estrangeira é importante mecanismo tradicional que permite dotar as decisões estrangeiras de eficácia em território nacional. Há, ainda entre os meios tradicionais, a extradição, que implica na entrega do indivíduo ao estado requerente. Na cooperação penal clássica, a autoridade judicial do país transmite o pedido, que passa ao ministério da justiça de seu estado, o qual retransmite ao ministério das relações exteriores do mesmo estado, que, por sua vez, comunica o ministério das relações exteriores do estado requerido. Este transmite o pedido ao ministério da justiça do estado requerido o qual finalmente o transmite ao juiz competente. Devido à demora procedimental que esse modelo requer é que os estados buscam cada vez mais formas de simplificar e acelerar a cooperação em matéria penal.

Foi com esse objetivo de simplificação que foram implementadas iniciativas regionais de cooperação penal, como as existentes na União Européia, no Mercosul e na OEA. A iniciativa européia, portanto, não é isolada e está inserida em um contexto global de forte tendência à maior cooperação penal. Para evidenciar essa conjuntura e para efeitos comparativos faz-se pertinente uma breve análise dos sistemas regionais, integrados pelo Brasil e que endereçaram o tema.

\section{O Brasil nos sistemas regionais}

O Brasil se utiliza principalmente, mas não só de mecanismos bilaterais de cooperação penal. Utiliza também instrumentos regionais e multilaterais de caráter global. Assim como a UE, o Brasil é estado parte na Convenção de Palermo contra o crime organizado trasnacional, de $2000^{3}$, que possui um escopo global. ${ }^{4}$ No âmbito regional o

2 A respeito dos mecanismos tradicionais TOFFOLI, José Dias. Mecanismos de cooperação jurídica internacional no Brasil. In: MINISTÉRIO DA JUSTIÇA. Manual de cooperação juridica internacional e recuperação de ativos. Brasília: 2008. p. 24-25.

3 A Convenção de Palermo foi adotada em 2000 e prevê parâmetros para tipificações criminais que recebem especial atenção da comunidade internacional, sobretudo por estarem relacionadas ao terrorismo. No Brasil foi aprovada pelo decreto legislativo 231, de 29.05.2003 e promulgado pelo decreto 5015, de 12.03.2004. Para versão oficial promulgada consultar: <http://www.planalto.gov.br/ccivil_03/_Ato2004-2006/2004/ Decreto/D5015.htm>. Acesso em: 19 abr. 2010.

+ O Brasil é signatário dos seguintes instrumentos internacionais de alcance global: Convenção das Nações Unidas contra o crime organizado transnacional (Convenção de Palermo); Protocolo adicional das Nações Unidas contra o crime organizado transnacional relativo ao combate ao trafico de migrantes por via terrestre marítima e aérea; Protocolo adicional das Nações Unidas contra o crime organizado transnacional relativo à prevenção, repressão e punição do trafico de pessoas, em especial mulheres e crianças; Convenção sobre o combate à corrupção de funcionário públicos estrangeiros em transações comerciais internacionais; Convenções de Genebra destinadas a proteger prisioneiros de guerra; Protocolo facultativo à Convenção sobre os direitos das crianças relativo ao envolvimento de crianças em conflitos armados e Protocolo facultativo à Convenção sobre direitos das crianças referente a venda de crianças, a prostituição infantil e a pornografia infantil. 
Brasil faz parte da Convenção interamericana sobre o cumprimento de sentenças penais no exterior, ${ }^{5}$ que prevê que as sentenças impostas em um dos estados a nacionais de outro estado poderão ser cumpridas no estado do nacional; e da Convenção interamericana sobre tráfico internacional de menores, ${ }^{6}$ que busca implementar meios para assegurar a restituição do menor vítima do tráfico internacional e estabelecer a competência para conhecer de delitos relativos ao tráfico internacional de menores.

Ainda no âmbito regional, o Brasil faz parte do Protocolo de assistência jurídica mútua em assuntos penais do Mercosul, que entrou em vigor 2000 apenas quatro anos após sua assinatura. ${ }^{7}$ Regula não apenas a solicitação de provas e diligências, mas também o cumprimento de sentenças e a entrega de indivíduos. Abrange, portanto, todos os aspectos endereçados pelos tradicionais mecanismos de cooperação judicial (carta rogatória, homologação de sentença estrangeira e extradição). O Protocolo prevê uma autoridade central em cada país responsável por receber e transmitir os pedidos de assistência jurídica. Esse modelo já constitui uma evolução em relação à cooperação penal clássica, a qual é eminentemente diplomática.

Em uma região de integração como a existente no Mercosul, em que o fluxo de pessoas, serviços, capitais e mercadorias é mais intenso, surge naturalmente uma maior necessidade de integração das informações no combate aos ilícitos transfronteiriços, que tendem a expandir-se pela facilidade de suas trocas. Diante dessa realidade, os mecanismos multilaterais de cooperação tendem a ganhar maior relevância em detrimento dos mecanismos bilaterais e os regionais, em detrimento dos globais. Essas afirmações aplicam-se igualmente - ou até mesmo em maior intensidade - à UE devido ao seu avançado processo de integração. Assim, é possível estabelecer um paralelo entre os fenômenos de cooperação que vem se desenvolvendo no bloco europeu e no bloco mercosulino.

5 A Convenção interamericana sobre o cumprimento de sentenças penais no exterior foi aprovada pelo decreto legislativo 293, de 12.07.2006 e promulgada pelo decreto 5919, de 03.10.2006. Para versão oficial promulgada consultar: <http://www2.mre.gov.br/dai/m_5919_2006.htm>. Acesso em: 19 abr. 2010.

6 A Convenção interamericana sobre tráfico internacional de menores foi aprovada pelo decreto legislativo 105, de 30.08.1994 e promulgada pelo decreto 2740, de 20.08.1998. Para versão oficial promulgada consultar: <http://www2.mre.gov.br/dai/tr\%C3\%Alficomenores.htm>. Acesso em: 19 abr. 2010.

7 Aprovado pelo decreto legislativo 03, de 26.01.2000 e promulgado pelo decreto 3468 de 17.05.2000. Para versão oficial promulgada consultar: <http://www2.mre.gov.br/dai/mercopenal.htm>. Acesso em: $19 \mathrm{abr}$ 2010. 
Desenvolvimento da cooperação penal na União Européia

Os antecedentes da cooperação na UE

Pode se dizer que a Convenção européia de extradição de $1957,{ }^{8}$ foi o marco inicial de uma cooperação em matéria penal entre os países integrantes do Conselho da Europa. Entre o fim dos anos cinqüenta e o início dos anos noventa, foi nesse fórum que ocorreu a maior parte dos esforços de cooperação em matéria penal, ${ }^{9}$ uma vez que as Comunidades Européias tinham sua atuação ainda bastante restrita.

A conjuntura que se desenvolveu ao longo dos anos 80 apontou para a necessidade de uma cooperação penal mais estreita e que se desse no seio da União Européia. São durante esses anos que os estados se vêem às voltas com o problema de atentados, como os do grupo RAF (Rote Armee Fraktion), na Alemanha e as Brigadas Vermelhas, na Itália. ${ }^{10}$

Já no ano de 1985, o Acordo Schengen" foi assinado, entre Alemanha, Bélgica, França, Luxemburgo e Países Baixos, com o objetivo de liberalizar a circulação de pessoas entre esses países. Essa abertura de fronteiras foi importante precedente para o que viria a ser cooperação em assuntos penais dentro da UE. O Acordo Schengen foi paradigmático, por instituir novos parâmetros na livre circulação de pessoas, razão pela qual foi posteriormente (em 1999) incorporado, juntamente com o restante de seu acervo ${ }^{12}$ ao Tratado da UE. A liberalização na circulação de pessoas trouxe como conseqüência a necessidade de maior cooperação em assuntos penais entre os Estados-Membros. O artigo 19 do Acordo Schengen já previa uma harmonização nas legislações em três matérias, sendo que duas delas imediatamente ligadas à cooperação penal: no que diz respeito a estupefantes, a armas e explosivos e à declaração dos viajantes nos hotéis. Já se

Foi aprovada em Portugal pela Resolução da Assembléia da República n. ${ }^{\circ} 23 / 89$, de 21.08.1989. Para versão oficial aprovada consultar: <http://www.gddc.pt/cooperacao/materia-penal/textos-mpenal/ce/rar-23dr-191-1989.html> Acesso em: 19 abr. 2010.

9 Tratavam de cooperação penal, no âmbito do Conselho da Europa os seguintes instrumentos: Convenção européia de extradição; Primeiro protocolo adicional à Convenção européia de extradição; Segundo Protocolo adicional à Convenção européia de extradição; Convenção européia de auxilio judiciário mútuo em matéria penal; Protocolo adicional à convenção européia de auxílio judiciário mútuo em matéria penal; Convenção européia para a repressão do terrorismo, e Convenção relativa ao branqueamento, detecção, apreensão e perda dos produtos do crime.

10 DAVIN, João. A criminalidade organizada transnacional. 2. ed. Coimbra: Almedina, 2007. p. 121.

"JO das Comunidades Européias L 239 de 22.09.2000 p. 13-18. Disponível em: <http://eurlex.europa.eu/LexUriServ/LexUriServ.do?uri=CELEX:42000A0922\%2801\%29:PT: HTML>. Acesso em: 24 maio 2010.

12 O acervo Schengen é composto pelo Acordo Schengen, de 1985, e pela Convenção Schengen, assinada em 1990 e em vigor a partir de 1995. 
reconhecia, portanto as implicações que a liberalização das fronteiras teriam em matéria de direito penal.

Da mesma forma que o Acordo Schengen, o Ato Único Europeu ${ }^{13}$ implantou novas dimensões no processo de integração, que passaram a ser cruciais para a percepção da necessidade de se promover uma cooperação em assuntos penais no seio da União Européia. Com a entrada em vigor do Ato Único Europeu, de 1987, implementou-se na Comunidade Econômica Européia um mercado interno sem barreiras.

A liberalização de pessoas, fruto do Acordo Schengen e a consolidação de um mercado único tornam premente a necessidade de estabelecer métodos de cooperação que fossem além dos clássicos, daí porque os instrumentos jurídicos de integração que se seguiram terem se preocupado, ainda que de forma bastante tímida, em endereçar a questão da cooperação penal.

\section{O Tratado de Maastricht}

Diante da conjuntura e do estágio de integração em que se encontravam as Comunidades Européias, o Tratado de Maastricht, ${ }^{14}$ de 1992, veio a implementar importantes mudanças, inclusive no quadro jurídico e institucional de cooperação matéria penal. É um marco importante e que introduz a cooperação em matéria penal na esfera de atuação da União Européia. Com isso foi possível dotar de maior grau de institucionalização a cooperação que já se desenvolvia entre os estados, mas de forma ainda esparsa.

Só a partir da entrada em vigor o Tratado de Maastricht é que se passa a falar de União Européia, que tem como base três pilares: as comunidades européias (primeiro pilar), a política externa e de segurança comum (segundo pilar) e a cooperação nos âmbitos de justiça e assuntos internos, conhecida como CAJAI (terceiro pilar). No segundo e terceiro pilar, disciplinados pelo Tratado da União Européia, prevalecia o regime de cooperação, de forma que as decisões deviam ser tomadas por unanimidade. Por sua vez o Tratado que Institui as Comunidades Européias tratava do primeiro pilar, ao qual eram afetas à Comunidade Européia matérias como livre circulação de mercadorias, comércio, política agrícola e circulação de trabalhadores. Prevalecia a supranacionalidade e os Estados-Membros deliberavam por maioria. ${ }^{15}$

A introdução da cooperação penal na União Européia tinha nos anos 90 naturalmente muitas limitações. Apenas o Conselho, composto pelos representantes

\footnotetext{
13 JO das Comunidades Européias L 169 de 29.06.1987, p. 1-29.

14 JO das Comunidades Européias C 224 de 31.08.1992, p. 1-130.

15 Essa divisão estrutural em pilares prevaleceu até 2009, quando da entrada em vigor do Tratado de Lisboa, que abandonou a distinção entre União Européia e Comunidade Européia, ao integrar os três pilares em um único tratado constitutivo e em um Tratado sobre o Funcionamento da União.
} 
dos estados a nível ministerial, detinha o poder de decisão que deveria ser tomada por unanimidade. A iniciativa sobre a matéria cabia a qualquer Estado-Membro ou à Comissão. O Parlamento ainda detinha um papel secundário, influenciando muito pouco as decisões. Também a competência do Tribunal de Justiça das Comunidades Européias era bastante estreita. Em termos de cooperação penal, podia atuar tão somente em dois casos: se alguma convenção concluída dentro da estrutura do terceiro pilar assim o determinasse, ${ }^{16} \mathrm{ou} \mathrm{em}$ caso de conflito de competência com a Comunidade Européia. ${ }^{17}$

A UE dispunha então para exercer sua competência em matéria de cooperação penal de três instrumentos: posições comuns, ações comuns e convenções. As posições comuns definiam como seria a abordagem da União em relação a cada assunto. Como exemplo, o Conselho determinou na posição comum 97/783/JAI de $1997^{18}$ a posição a ser defendida pelos seus Estados-Membros quanto à convenção da OCDE no que tange a corrupção a nível internacional. As ações comuns implicavam uma maior coordenação na ação dos Estados-Membros, mas foram extintas pelo Tratado de Amsterdã, que entrou em vigor em 1999. Por seu turno, as convenções, elaboradas e recomendadas pelo Conselho destinavam-se a criar uma base comum para a proteção penal de determinadas matérias. Entravam em vigor nos Estados-Membros aderentes após terem sido adotadas por pelo menos metade deles.

Apesar da UE dispor desses instrumentos para implementar uma política de cooperação penal, ela não pôde evoluir significativamente até a posterior modificação do tratado constitutivo da UE que viria a ser feita pelo Tratado de Amsterdã. ${ }^{19}$ Para Sousa, pode-se resumir o insucesso da política de cooperação penal que se originou no Tratado de Maastricht em cinco aspectos: ${ }^{20} 1$.) ausência de objetivos claros, 2.) de um projeto político planificado, 3.) inoperacionabalidade dos mecanismos institucionais e jurídicos, uma vez que eram excessivamente burocráticos e inapropriados, 4.) o limitado papel atribuído ao Parlamento Europeu, 5.) a ausência de controle jurisdicional.

As falhas naturais do primeiro esforço de cooperação penal sistemática puderam orientar as medidas necessárias ao aprimoramento da matéria. Tendo em conta as críticas levantadas foi possível implementar, quando da reforma do TUE pelo Tratado de Amsterdã, uma política de cooperação penal mais clara e com sentido mais prático.

\footnotetext{
Artigo K.3, n. 2 do Tratado de Maastricht.

Leitura conjugada dos artigos L e M do Tratado de Maastricht.

JO das Comunidades Européias L 320 de 21.11.1997, p. 1.

JO das Comunidades Européias C 340 de 10.11.1997, p. 1.

SOUSA, Constança Urbano de. O novo terceiro pilar na União Européia: a cooperação policial e judiciária em matéria penal. In: DIAS, Jorge de Figueiredo (Org.). Estudos em homenagem a Cunha Rodrigues. Coimbra: Coimbra Editora, 2001.p. 878-880.
} 


\section{O Tratado de Amsterdã}

Com o Tratado de Amsterdã a cooperação penal passou por profundas mudanças. É a partir de então que se consubstancia a idéia de um espaço europeu de liberdade, segurança e justiça, fazendo com que se atinja um novo nível de integração européia para além do objetivo único de integração econômica-comercial - a qual até então orientava as medidas de integração. Vê-se pois que a cooperação em matéria penal passa a integrar um objetivo maior de construção de um espaço europeu protegido e segurado.

No ano de 1999, com a entrada em vigor do Tratado de Amsterdã, a antiga cooperação nos âmbitos de justiça e assuntos internos ${ }^{21}$ passou a denominar-se cooperação policial e judicial em matéria penal. Parte dos assuntos antes tratados pela CAJAI questões cíveis e de asilo e imigração - foram comunitarizadas, ${ }^{22}$ restando ao Tratado da União Européia tratar tão somente da cooperação em matéria penal. Além disso, o Acordo Schengen passou a integrar o acervo da EU, por meio do Protocolo n. 2 anexo ao Tratado de Amsterdã. Nas lições de Sousa "O enquadramento normativo do espaço de liberdade, segurança e justiça revela-se pois extremamente complexo e fragmentário, traduzindo-se na existência de três blocos normativos diferentes, embora subordinados à realização de um mesmo objetivo" ${ }^{23}$ Esses blocos normativos seriam, a disciplina do título VI do TUE; do título IV, parte II do TCE e do Acervo Schengen.

No mesmo ano em que entrou em vigor o Tratado de Amsterdã, o Conselho Europeu reuniu-se em sessão extraordinária, na cidade de Tampere, para discutir criação de um espaço de liberdade, segurança e justiça na UE. Afirmaram-se alguns princípios que deveriam orientar o desenvolvimento da União Européia a partir daquele momento, como o reconhecimento mútuo de decisões judiciais e cooperação em matéria de luta contra a criminalidade. Também foi durante o Conselho de Tampere que se decidiu pela criação da Eurojust, que tem até hoje como objetivo coordenar a ação de magistrados e promotores contra o crime transnacional. ${ }^{24}$

Com o Tratado de Amsterdã foram introduzidos novos instrumentos jurídicos de atuação da UE. Ao Conselho foi permitido celebrar acordos internacionais na área de cooperação penal. Desapareceram as ações comuns, dando lugar às decisões e decisõesquadro, de forma que a UE passava a contar com: (1) posições comuns, (2) decisões, (3) decisões-quadro e (4) convenções. As decisões-quadro visavam aproximar disposições legislativas, mas não possuíam efeito direto, apesar de vincularem os Estados-Membros

\footnotetext{
21 Sobre a CAJAI cf. p. 8.

?2 Há uma exceção à comunitarização da matéria em relação a Dinamarca, que não ratificou o título IV reformado do TCE. Cf. p. 14.

23 SOUSA, Constança Urbano de. op. cit., p. 878-880.

24 O papel da Eurojust será estudado com mais profundidade no capitulo 4.5.1.
} 
quanto ao resultado. Encontram-se ainda em vigor, decisões-quadro como aquela relativa à luta contra o terrorismo (2002/475/JAI), que prevê as infrações terroristas a serem assim consideradas pelo direito nacional dos Estados-Membros. ${ }^{25}$ A decisão-quadro, portanto, estabelecia parâmetros mínimos para um tratamento menos heterogêneo em relação a matérias muito caras à União Européia. Outras decisões-quadro do Conselho são relativas: à luta contra o tráfico de seres humanos (2002/629/JAI), ao combate à corrupção no setor privado (2003/568/JAI), à luta contra a exploração sexual de crianças e a pornografia infantil (2004/68/JAI), e à adoção de regras mínimas quanto aos elementos constitutivos das infrações penais e sanções aplicáveis no domínio do tráfico ilícito de droga (2004/757/ JAI). ${ }^{26}$

As decisões, diferentemente das decisões-quadro, estabeleciam certos objetivos, mas sem esse caráter de harmonização, possuíam efeito vinculativo, mas indireto. Embora a convenção já existisse antes como instrumento, ela ganhou força ao atribuir ao Conselho o poder de estabelecer prazos para que os Estados-Membros iniciassem o processo de ratificação. Também se previu que as convenções entrariam em vigor após metade dos Estados-Membros terem-nas ratificado.

Essa tipologia normativa especifica para assuntos de cooperação penal foi inteiramente abandonada pelo Tratado de Lisboa em 2009, que fez com que se aplicassem ao domínio da cooperação penal os mesmos atos normativos pertencentes ao âmbito de competência da antiga Comunidade Européia.

O Tratado de Amsterdã também introduziu o instrumento da cooperação reforçada, o qual existe até hoje. Mediante a cooperação reforçada apenas alguns EstadosMembros se comprometem a um acordo que eleve o nível de cooperação e integração. A idéia é que a negação de alguns Estados-Membros para aumentar os laços de cooperação não afete a busca por uma integração mais estreita por parte de outros Estados-Membros. Além disso, o instrumento de cooperação reforçada permite que se implementem novos mecanismos de integração e que se observem os seus efeitos, de modo a possivelmente estender a medida a outros Estados-Membros no futuro. É uma forma de aumentar o nível de integração paulatinamente possibilitando um melhor ajuste do sistema jurídico dos Estados-Membros. Permite ainda a experimentação à partir de formas inovadoras de cooperação.

Outra novidade introduzida pelo Tratado de Amsterdã diz respeito às atribuições dos órgãos europeus. O Conselho continua a ter um papel legislativo. A

25 JO das Comunidades Européias L 164 de 22.6.2002, p. 3.

26 Respectivamente no JO das Comunidades Européias L 203 de 1.8.2002, p. 1; JO da União Européia L 192 de 31.7.2003, p. 54; JO da União Européia L 13 de 20.1.2004, p. 44 e JO da União Européia L 335 de 11.11.2004, p. 8. 
Comissão, que possui membros independentes e não representa a vontade dos EstadosMembros, também ganhou poderes, ao partilhar o direito de iniciativa com os EstadosMembros. O Parlamento Europeu, eleito diretamente pelos cidadãos, passa a emitir pareceres previamente à adoção de decisões, decisões quadro e convenções. Há, ao longo das reformas européias, uma crescente tendência em se fortalecer o papel do Parlamento Europeu. Essa tendência deve ser especialmente fortalecida em um campo tão sensivel aos interesses democráticos, como o da cooperação penal, que afeta diretamente os direitos e liberdades do cidadão.

Tendo em vista a necessidade de legitimação democrática, o Protocolo 5 e 6 anexo ao antigo TUE previa a competência dos parlamentos nacionais, por meio da Conferência dos órgãos especializados em assuntos comunitários, para analisar as iniciativas que viessem a influir diretamente em liberdades individuais, no âmbito do espaço de liberdade, segurança e justiça.

O Tribunal de Justiça das Comunidades Européias (TJCE) também recebeu um novo papel. O Tratado da União Européia, conforme sua redação dada pelo Tratado de Amsterdã, previa então em seu artigo 34, n. 1 que o TJCE tinha competência para decidir, de forma prejudicial, sobre a validade e interpretação das decisões-quadro, das decisões e também das convenções que tratassem da cooperação penal. Para tanto, era necessário que o Estado-Membro fizesse declaração expressa sobre essa aceitação, no momento da assinatura do Tratado de Amsterdã. A aceitação poderia prever envio prejudicial por qualquer órgão interno ou apenas pelos órgãos jurisdicionais, cujas decisões fossem irrecorríveis. A grande maioria dos estados optou por essa última possibilidade. O EstadoMembro poderia ainda, de acordo com a declaração n. 10 do Tratado de Amsterdã, dispor internamente que os seus órgãos deveriam obrigatoriamente enviar a questão prejudicial ao TJCE. Assinaram a declaração n 10 Alemanha, Espanha e França. Portugal aceitou a competência do TJCE, mas não tornou o envio prejudicial obrigatório. O Reino Unido, por sua vez, sequer aceitou a jurisdição do TJCE.

Vê-se pois que o Tratado de Amsterdã provocou profundas mudanças no quadro jurídico da cooperação penal da União Européia, sendo um importante marco na evolução do tema rumo à efetiva comunitarização, que só viria a acontecer em 2009 com o Tratado de Lisboa.

\section{O Tratado de Nice}

O Tratado de $\mathrm{Nice}^{27}$ teve como principal atributo a reforma das instituições européias, a fim de serem recebidos os novos Estados-Membros que viriam a integrar a

2: JO das Comunidades Européias C 80 de 10.3.2001, p. 1. 
UE. Ao entrar em vigor em $1^{\circ}$ de fevereiro de 2003 , facilitou a cooperação reforçada e introduziu no Tratado da União Européia as atribuições da Eurojust, que continua a ser importante órgão de realização da cooperação penal.

A cooperação reforçada era vista como um procedimento excessivamente rigoroso, que acabava por inibir a consecução de seu próprio objetivo. As mudanças sobre o tema, introduzidas pelo Tratado de Nice continuam em vigor. O número mínimo de Estados-Membros necessários à propositura da ação foi reduzido da maioria para oito. Feito o pedido, o Parlamento deve emitir parecer a respeito e o Conselho deve deliberar sobre a cooperação reforçada por maioria qualificada. Além disso, o direito de veto dos demais Estados-Membros em relação à cooperação reforçada foi eliminado. Ao ser instituída, a cooperação reforçada deve estar aberta a qualquer Estado-Membro, que dela queira fazer parte. Naturalmente as ações previstas dentro de uma cooperação reforçada devem estar em consonância com o processo de integração e no caso da cooperação penal isso significa realizar o espaço de liberdade, segurança e justiça.

A cooperação penal atual

A comunitarização da matéria

O Tratado de Lisboa, ${ }^{28}$ que entrou em vigor em $1^{\circ}$ de dezembro de 2009 , introduziu significativas mudanças no tratamento da cooperação penal. Certamente a novidade mais impactante é a que permite decisões não unânimes sobre cooperação em matéria penal, que passa a estar sujeita às regras da supranacionalidade. Mas outras inovações são igualmente importantes, como a da previsão de criação de uma Procuradoria Européia.

A antiga estrutura dos três pilares sofreu profundas alterações. A divisão sistemática de matérias foi modificada com o Tratado de Lisboa, que alterou o Tratado da União Européia e o Tratado de Comunidade Européia, dando a este o nome de Tratado sobre o Funcionamento da União Européia (TFUE). ${ }^{29}$ Assim, das três comunidades européias originárias (Comunidade econômica européia, Comunidade européia do carvão e do aço e Comunidade européia de energia atômica), passaram a existir apenas dois entes de integração: a União Européia, regida pelo Tratado da União Européia e pelo TFUE e a Euratom, regida pelo Tratado que institui a Comunidade Européia de Energia Atomica. ${ }^{30}$

28 JO da União Européia C 306 de 17.12.2007, p. 1 .

29 A nova versão do TUE e do TFUE foram publicados no JO da União Européia C 83 de 30.03.2010, p. 1-359, disponível em http://eur-lex.europa.eu/JOHtml.do?uri=OJ:C:2010:083:SOM:PT:HTML, acesso em 05.06.2010.

30 A CEEA foi criada em 1957 pelo Tratado de Roma. Possui personalidade jurídica distinta da União Européia, mas conta com as instituições desta para a elaboração de seus trabalhos. A versão oficial do Tratado que 
A cooperação penal - assim como a PESC - deixa de ter um tratamento isolado e especial no TUE e passa ser disciplinada juntamente com as demais matérias de competência da União Européia. Se antes havia uma fronteira que separava a competência da Comunidade Européia quanto às políticas de livre circulação de pessoas da competência da União Européia em matéria de cooperação penal, essa linha desaparece a partir da entrada em vigor do Tratado de Lisboa. A cooperação penal passa a integrar o título $\mathrm{V}$ do TFUE, que dispõe sobre o espaço de liberdade, segurança e justiça. Essa mudança é significativa ao colocar sob a mesma disciplina matérias profundamente interligadas deslocamento populacional e cooperação penal - uma vez que a intensificação da primeira aumenta a necessidade de se aprimorar a segunda.

Em verdade, os assuntos de justiça interna já eram conjuntamente disciplinados até o Tratado de Amsterdã. Neste tratado, porém, houve uma separação de assuntos de justiça interna com a finalidade de tornar algumas questões comunitárias, já que naquele momento era inviável a comunitarização também dos assuntos penais. Foi, portanto, natural que com as reformas do Tratado de Lisboa se quisesse tratar dos assuntos de justiça interna novamente de uma forma conjunta.

\section{O caso da Dinamarca}

A aplicação das disposições sobre o espaço de liberdade, segurança e justiça, foi excepcionada para a Dinamarca. De acordo com o Protocolo sobre a posição da Dinamarca, anexo ao TFUE, as medidas tomadas no âmbito da parte III, capítulo V não se aplicam à Dinamarca, de forma que ela não esta vinculada aos atos da União em relação a esses temas. Tendo em vista a não aplicação das decisões sobre o tema à Dinamarca, o seu voto não entra para o computo da unanimidade, nos casos em que ela for exigida para aprovação de alguma medida. O Estado-Membro tampouco está sujeito ao controle jurisdicional com respeito à não aplicação de medidas européias em relação ao espaço de liberdade, segurança e justiça. Assim, ao se analisar a legislação européia e sua aplicação em relação à cooperação penal, deve se ter em mente que as disposições não se aplicam necessariamente à Dinamarca, podendo haver conflito de disposições. Isso pode levar a dificuldades na implantação de um espaço integrado de proteção ao cidadão.

Instrumentos de atuação e processo legislativo

Apesar do Tratado de Lisboa, as instituições pertencentes à União Européia permaneceram inalteradas, mudando em certa medida o campo de ação de cada uma.

institui a Euratom está disponível em: $<$ http://eur-lex.europa.eu/pt/treaties/index.htm>. Acesso em: 27 maio 2010. 
Assim, o Parlamento Europeu continua a ter função legislativa, orçamental e de controle, mas sua margem de atuação foi ampliada. Passa a ter um papel mais decisivo em um maior número de matérias, sobre as quais anteriormente emitia meramente pareceres. Agora também as decisões em matéria de cooperação penal passam a estar sujeitas à aprovação do Parlamento. O fortalecimento do Parlamento Europeu responde à demanda por uma maior representatividade dos interesses dos cidadãos no processo de integração. O aprimoramento do papel do Parlamento foi a contrapartida necessária à ampliação das competências da União Européia, que passa a ter cada vez mais influência na vida de seus cidadãos.

A definição dos rumos a serem tomados para implantação do espaço de liberdade, segurança e justiça cabe ao Conselho, conforme o art. 68 do TFUE e de acordo com a competência geral a ele atribuída pelo art. 13 do TUE. Definidas as orientações, compete à Comissão Européia ou aos Estados-Membros propor projetos legislativos. Essa atribuição compartilhada, entre Comissão e Estados-Membros, para propor projetos já existia no antigo TUE, mas não se previa um número mínimo de Estados-Membros para a propositura normativa. Agora, com o Tratado de Lisboa, a iniciativa dos EstadosMembros deve ser feita por pelo menos um quarto deles, não podendo mais ser individual.

Com o Tratado de Lisboa a tipologia dos atos normativos aptos a disciplinar a cooperação penal, foi completamente alterada. A unificação dos temas no Tratado de Funcionamento da União Européia fez com que os atos normativos utilizados pela União para dispor sobre o tema passassem a ser os mesmos atos atinentes às outras matérias. As posições comuns, decisões, decisões-quadro e convenções foram substituídas pelos mecanismos comunitários tradicionais: (1) regulamentos, (2) diretivas, (3) decisões, (4) recomendações e (5) pareceres.

A denominação e as características de cada um deles foram praticamente mantidas intactas pelo Tratado de Lisboa. De acordo com o art. 288 do TFUE os regulamentos são diretamente aplicáveis, tendo caráter geral e obrigatório. Podem, portanto, superar desde logo a barreira da soberania estatal, afetando imediatamente as pessoas físicas e jurídicas. ${ }^{31}$ As diretivas vinculam o Estado-Membro apenas em relação ao resultado. A decisão também é obrigatória. Se porventura vier a designar os destinatários aplicar-se-á somente a estes. Nesse sentido, houve uma mudança introduzida pelo Tratado de Lisboa. Anteriormente, as decisões eram obrigatórias para os destinatários designados, de forma que a decisão necessariamente tinha que apontá-los, sob pena de que não fosse aplicada em nenhum Estado-Membro. Agora, se nenhum destinatário for designado, ela é

31 PISTOIA, Emanuela. Cooperazione penale nei rapporti fra diritto dell'Unione Europea e diritto statale. Napoli: Scientifiche Italiane, 2008. p. 319. 
obrigatória a todos os Estados-Membros. Assim, a regra da designação dos destinatários tornou-se exceção. Já as recomendações e pareceres continuam a ter caráter não vinculante.

Os atos voltados à cooperação penal passam a seguir a tramitação do procedimento ordinário, que está prevista no art. 294 do TFUE. ${ }^{32}$ Essa é uma das mais impactantes mudanças em relação à cooperação penal, gerando grande celeuma. Anteriormente ao Tratado de Lisboa as decisões do Conselho sobre o tema dependiam de aprovação unânime, conforme previa o art. 34, n. 2 do antigo TUE. Com as mudanças introduzidas, essa decisão passa a ser submetida também ao Parlamento, mas não requer para aprovação dos atos a decisão consensual e sim por uma maioria. Apenas em alguns casos previstos expressamente pelo tratado é que será admitido outro procedimento de aprovação. Nesse caso cada matéria conterá previsão própria sobre os atos extraordinários necessários.

Essa mudança no processo decisório provocou inúmeros questionamentos acerca da legitimidade da UE para dispor sobre o direito penal, uma vez que norma européia sobre o direito penal pode entrar em vigor em um Estado-Membro mesmo que o representante deste tenha votado contra a medida. Assim, seria possível que a norma passase a ser aplicada aos cidadãos de um país, sem que seus representantes tivessem votado à favor. Aprovar normas penais dessa forma é comum aos estados nos moldes tradicionais, pois pelo menos uma parcela daquela coletividade nacional aprovou a medida. Porém, quando isso ocorre a nível supranacional, é possível que absolutamente nenhum indivíduo dentro de um Estado-Membro específico concorde com aquela norma, que ainda sim será imposta. ${ }^{33}$

32 O processo ordinário tem a seguinte tramitação: A Comissão apresenta sua proposta ao Parlamento e ao Conselho. Este então aguarda que o Parlamento lhe transmita sua posição. Em seguida o Conselho delibera e se aprovado o ato passa a ser adotado. Se não aprovado o ato não se insere no mundo jurídico. O Conselho pode ainda emendar o ato. Esta emenda deve ter aprovação unânime, pois o art. 293, n. I prevê que o Conselho ao alterar proposta da Comissão deve fazê-lo mediante consenso. A proposta alterada é então transmitida ao Parlamento, o qual também recebe um informe sobre a posição da Comissão. Em seguida o Parlamento delibera novamente sobre o ato, uma vez que este sofreu alterações. O Parlamento pode então aprová-lo e nesse caso o ato passa a ser adotado. Entretanto, se ele for rejeitado não passará a integrar o mundo jurídico. $\mathrm{O}$ ato pode ainda sofrer um segundo processo de emenda se a maioria absoluta do Parlamento assim o desejar. Nesse caso o novo projeto é enviado novamente ao Conselho e à Comissão. $\mathrm{O}$ Conselho após parecer da Comissão delibera então sobre o ato. Se aprovado o ato é adotado. Porém, se o parecer da Comissão for em sentido negativo, o Conselho só pode aprovar o ato por unanimidade. Se não aprovado o ato, o presidente do Conselho e o presidente do Parlamento convocam, em até 6 semanas um Comitê de Conciliação. Este comitê, que deverá decidir por maioria qualificada, pode rejeitar o projeto, hipótese na qual o ato não passará a existir, ou pode aprovar o projeto. Aprovado o projeto ele será submetido ao Parlamento e ao Conselho em separado. O Parlamento deve aprovar o projeto por maioria simples, enquanto que o Conselho deve aprová-lo por maioria qualificada.

33 A discussão acerca da supranacionalidade aplicável às normas penais será retomada no capítulo 5.1. 
Objetivos e princípios da cooperação penal

A comunitarização da cooperação penal alterou o modo de atuação da UE em relação ao tema. Müller-Graff assinala que houve uma mudança na natureza jurídica do espaço de liberdade, segurança e justiça. ${ }^{34}$ Entretanto, o objetivo por detrás dessa cooperação continua a ter como orientação o mesmo espaço do qual já se falava no Tratado de Amsterdã.

Em seu art. $3^{\circ}$ n. 2 o TUE enuncia entre seus objetivos garantir um espaço de liberdade, segurança e justiça em conjugação com medidas adequadas de prevenção da criminalidade e combate a ela. ${ }^{35}$ Agora, ao estabelecer as diretrizes e objetivos da União Européia o TUE deixa a cargo do TFUE as disposições específicas. Assim, o título V do TFUE consolidou as disposições do título VI do antigo TU e do título IV do extinto TCE.

$O$ art. 67, n. 3 do TFUE estabelece que:

3. A União envida esforços para garantir um elevado nível de segurança, através de medidas de prevenção da criminalidade, do racismo e da xenofobia e de combate contra estes fenómenos, através de medidas de coordenação e de cooperação entre autoridades policiais e judiciárias e outras autoridades competentes, bem como através do reconhecimento mútuo das decisões judiciais em matéria penal e, se necessário, através da aproximação das legislações penais.

Manter um elevado nível de segurança é o objetivo ao qual devem servir as medidas anunciadas. O TFUE menciona dois gêneros de medidas. O primeiro se refere a medidas de prevenção e o segundo a medidas de combate aos ilícitos. Havendo essas duas medidas genéricas, o TFUE prevê três modalidades especificas de medidas que podem ser consideradas espécies, pois cada uma engendra em si o conceito de prevenção ou combate, ou ambos. Existem, portanto três espécies de medidas de atuação: (1) coordenação e cooperação (sendo que elas se subdividem em policial e judiciária), (2) reconhecimento mútuo de decisões judiciais e (3) aproximação legislativa. Diante desse quadro serão discutidas essas três espécies de medidas de atuação.

34 MÜLLER-GRAFF, Peter-Cristian. Der Raum der Freiheit, der Sicherheit und des Rechts in der Lissabonner Reform. In: SCHWARZE, Jürgen; HATJE, Armin. Der Reformvertrag Von Lissabon. Baden-Baden: Nomos, 2009. p. 119.

35 A mesma previsão já existia no antigo art. $2^{\circ}$, parágrafo $4^{\circ}$ do TUE. 
Coordenação e cooperação judicial

Eurojust

A coordenação entre autoridades nacionais competentes para o exercício da investigação e ação penal é exercida pela Eurojust, idealizada estabelecida em 2002 pela decisão interna 2002/187/JAI. ${ }^{36}$ Desde sua instituição a Eurojust goza de personalidade jurídica própria. O marco legal de criação da Eurojust, ainda em vigor, prevê no art. $3^{\circ}, \mathrm{n}$. 1 os objetivo da Eurojust:

a) Incentivo e melhoria da coordenação, entre as autoridades competentes do Estados-Membros, das investigações e procedimentos penais nos Estados-Membros, tendo em conta todo e qualquer pedido proveniente de uma autoridade competente de um Estado-Membro e todas as informações fornecidas pelos órgãos competentes nos termos das disposições aprovadas no âmbito dos Tratados;

b) Melhoria da cooperação entre as autoridades competentes dos EstadosMembros, facilitando, em particular, a prestação de auxílio judiciário mútuo em matéria penal no plano internacional e a execução dos pedidos de extradição;

c) Outras formas de apoio às autoridades competentes dos Estados-Membros para reforçar a eficácia das suas investigações e procedimentos penais.

O Tratado de Lisboa atribuiu à Eurojust diversas competências novas. $\mathrm{O}$ art. $85, \mathrm{n}^{\circ} 1$ do TFUE elenca um rol de matérias sobre as quais ela pode atuar. Está expressamente previsto que além de coordenar a Eurojust pode também propor ações e investigações criminais junto às autoridades nacionais. A Eurojust pode também solucionar conflitos de jurisdição, conforme art. 85, $\mathrm{n}^{\circ} 1$, alínea c.) do TFUE. As funções da Eurojust podem ainda incluir outras medidas a serem estendidas por meio do processo legislativo ordinário

Há, portanto, a partir de 2009, uma substancial mudança no papel desse órgão, já que o antigo TUE apenas atribuía a função de facilitar a coordenação adequada, e já que o instrumento de criação da Eurojust menciona apenas medidas de incentivo e apoio. A Eurojust ganha com o TFUE um papel mais ativo, chegando a propor às autoridades nacionais instauração de investigação e processo e a solucionar conflitos de jurisdição. Importante frisar que os atos do procedimento judicial são executados por agente nacionais.

A função de avaliação das atividades da Eurojust foi atribuída aos parlamentos nacionais através do art. 85, n. 2 do TFUE. O fundamento é garantir que a Eurojust exerça na medida exata suas competências. Na realidade, a preocupação em se

36 JO das Comunidades Européias L 63 de 06.3.2002, p. 1. 
assegurar um maior controle por parlamentares nacionais de um assunto tão sensível já podia ser vista no Tratado de Amsterdã, nos Protocolos 5 e 6 a ele anexos. Assegurava-se que a Conferencia dos órgãos parlamentares nacionais especializados em assuntos europeus (COSAC) pudesse analisar as iniciativas legislativas relacionadas ao espaço europeu de liberdade, segurança e justiça caso tivessem incidência direta em direito e liberdade individuais. A idéia, portanto, de atribuir aos Parlamentos nacionais um mecanismo de controle já existia, mas foi aprimorada com o Tratado de Lisboa.

\section{A Procuradoria européia}

O Tratado de Lisboa introduziu mais uma relevante mudança no quadro da UE: possibilitou a criação da Procuradoria Européia. Em verdade a idéia de uma Procuradoria Européia não é nova, mas só foi consubstanciada em Lisboa, em razão dos intensos debates que a antecederam. Em 2001 foi apresentado pela Comissão um Livro Verde sobre a proteção dos interesses financeiros da UE, ${ }^{37}$ no qual já se previa a necessidade de um procurador europeu. Houve grande resistência à criação de um Ministério Público Europeu, havendo quem o rejeitasse por completo e havendo quem defendesse que esse papel deveria ser atribuído à Eurojust. Lopes da Mota assinala muito bem os problemas que levaram à necessidade de criação e uma procuradoria européia: "O défice de eficácia da cooperação judiciária, para dar continuidade à acção administrativa do OLAF, resultante da fragmentação do espaço judiciário europeu e das diferenças de leis e sistemas penais, apelava a uma nova abordagem" 38

O Organismo europeu de luta antifraude (OLAF), criado pela decisão da Comissão 1999/352/CE ${ }^{39}$ tem por objetivo defender os interesses financeiros da União Européia. Mas, o papel do OLAF é meramente administrativo. Ainda que detenha alguns poderes limitados de investigação não tem legitimidade para exercer ação penal, nem tão pouco para aplicar sanções. Nesse sentido assemelha-se às corregedorias do âmbito interno estatal. Em vista dessa deficiência na defesa dos interesses da União Européia é que afinal se acabou por aceitar a instituição da Procuradoria Européia, que passaria a exercer um papel complementar ao OLAF.

$\mathrm{O}$ art. 86 do TFUE estabelece que a Procuradoria Européia poderá ser criada a partir da Eurojust. A Procuradoria Européia terá como função combater os atos lesivos aos interesses financeiros da União Européia, sendo competente para investigar e processar os

\footnotetext{
37 Comissão das Comunidades Européias, COM (2001) 715 final de 11.12.2001. Disponível em: <http://eurlex.europa.eu/LexUriServ/site/pt/com/2001/com2001_0715pt01.pdf>. Acesso em: 06 jun. 2010.

38 MOTA, José Luís Lopes da. A União Européia face à criminalidade transnacional: a caminho de um Ministério Público Europeu? p. 3. Disponivel em: <http://www.ieei.pt/files/Ministerio_Publico_Europeu_ Jose_Luis_Lopes_Mota.pdf>.Acesso em: 02 fev. 2010.

39 JO das Comunidades Européias L 136, de 31.05.1999, p. 20
} 
autores das respectivas infrações. Ela será titular da ação pública, a tramitar junto ao órgão competente dos Estados-Membros. Possui claramente maior poder que aquele atribuído ao OLAF. O OLAF, entretanto, não se torna dispensável diante da Procuradoria Européia. mas a coordenação da ação dos dois órgãos torna-se essencial para a proteção efetiva dos interesses da União.

Deve-se atentar para o fato de que a criação de uma Procuradoria Européia implica a necessidade de uma regulamentação das regras processuais aplicáveis à sua atividade. ${ }^{40}$ Ao exercer um papel ativo nas ações penais é preciso que se tenha regras claras dos limites que tem para tanto, ainda que o processo transcorra junto à jurisdição do Estados-Membros. A atividade do procurador europeu deve ser passível de controle também por órgãos próprios da União Européia, assim faz-se necessário a instituição clara dos limites e instrumentos para atuação do procurador europeu.

O TFUE ainda reserva mais uma importante previsão no art. 86 , no $4^{\circ}$. ao permitir a extensão das competências da Procuradoria Européia para os crimes graves de dimensão transfronteiriça:

Artigo 86

4. O Conselho Europeu pode, em simultâneo ou posteriormente, adoptar uma decisão que altere o n. ${ }^{\circ}$, de modo a tornar as atribuições da Procuradoria Européia extensivas ao combate à criminalidade grave com dimensão transfronteiriça, e que altere em conformidade o n. ${ }^{\circ} 2$ no que diz respeito aos autores e cúmplices de crimes graves que afectem vários Estados-Membros. O Conselho Europeu delibera por unanimidade, após aprovação do Parlamento Europeu e após consulta à Comissão.

Com isso cria-se a real possibilidade de a União Européia, por meio de sua procuradoria, atuar como parte ativa em processo de condenação criminal, ainda que o bem jurídico protegido não seja o interesse financeiro da União. A previsão sofre naturalmente inúmeras críticas, sobretudo no que diz respeito ao déficit democrático. Mesmo, com a previsão de que nesse caso o Conselho Europeu delibera por unanimidade, representado, portanto o interesse de todos os Estados-Membros e mesmo que a Comissão seja consultada e o Parlamento aprove a medida, há uma extrema abdicação da soberania dos Estados-Membros em uma matéria bastante sensível. A aprovação de uma medida no sentido de estender a competência da Procuradoria Européia a outros crimes transnacionais certamente iria colidir com questões constitucionais no âmbito interno dos EstadosMembros. Por se tratar de uma previsão inovadora far-se-á necessário observar nos

40 SOUSA, Alfredo José de. A criminalidade transnacional na União Européia. Um ministério público europeu? Coimbra: Almedina, 2005. p. 155. 
próximos anos em que medida e de que maneira ela irá se materializar, mas a possibilidade de conflitos de competência entre União Européia e Estados-Membros é evidente.

O reconhecimento mútuo de decisões judiciais

Além da coordenação e cooperação exercida pela Eurojust, o reconhecimento mútuo de decisões judiciais é outro instrumento importante de integração inserido no âmbito da cooperação judicial penal.

Já em 1999, o Conselho Europeu pronunciou-se, em Tampere, no seguinte sentido:

\begin{abstract}
33. Um maior reconhecimento mútuo das sentenças e decisões judiciais e a necessária aproximação da legislação facilitariam a cooperação entre as autoridades e a protecção judicial dos direitos individuais. Por conseguinte, o Conselho Europeu subscreve o princípio do reconhecimento mútuo que, na sua opinião, se deve tornar a pedra angular da cooperação judiciária na União, tanto em matéria civil como penal. Este princípio deverá aplicar-se às sentenças e outras decisões das autoridades judiciais. ${ }^{41}$
\end{abstract}

Desde 1999, portanto, o princípio do reconhecimento mútuo já norteava as ações da União Européia, embora para fins penais só tenha sido explicitamente previsto no tratado constitutivo dez anos depois.

O art. 29 do TUE - na versão do Tratado de Nice - já previa o reconhecimento mútuo de decisões judiciais, preconizadas como necessárias à criação de um espaço europeu de liberdade, segurança e justiça. O TFUE introduziu uma nova previsão ao explicitar a necessidade de reconhecimento mútuo das decisões judiciais em matéria penal. Essa previsão não existia expressamente: o art. 65, alínea a, ítem 3 do TCE - na versão do Tratado de Nice - previa a melhora e simplificação do reconhecimento de decisões apenas em matéria civil e comercial. A mudança é importante uma vez que evidencia que o reconhecimento é importante medida para se manter o almejado nível de segurança. O reconhecimento mútuo de decisões judiciais passa a ser um princípio, não só para as questões cíveis (art. 67, n. 4), mas também para as questões penais (art. 82, n. 1).

Mas, se o reconhecimento de decisões deve estar baseado no respeito ao sistema dos Estados-Membros e na confiança mútua, uma análise crítica evidencia a necessidade de um suporte legal adequado, que permita a confiança devida entre os Estados-Membros. Esse suporte legal poderia ter como base as previsões da Carta de

41 Conclusões da presidência da reunião do Conselho Europeu de Tampere de 15 e 16 de outubro de 1999 Disponível em: <http://www.europarl.europa.eu/summits/tam_pt.htm>. Acesso em: 14jun. 2010. 
Direitos Fundamentais da UE, ${ }^{42}$ uma vez que o art. $6^{\circ}$ do TUE reconhece expressamente os direitos, liberdades e princípios enunciados por ela. Assim, os direitos fundamentais não só estabelecem os limites para o exercício do direito penal, mas também - em algumas circunstâncias - requerem e legitimam uma proteção que só o direito penal pode oferecer. ${ }^{4:}$

Embora as previsões da Carta de Direitos Fundamentais sejam bastante gerais, estabelecem: o direito de ação e tribunal imparcial, presunção de inocência, princípios da legalidade e proporcionalidade e non bis in idem. O desenvolvimento de outras previsões nesse sentido permitiria talvez uma elevação do grau de confiança entre as autoridades judiciais partes na cooperação penal. Naturalmente há que se manter certo grau de generalidade observando-se as tradições e regras do sistema penal processual e, sobretudo material de cada Estado-Membro.

A concretização dos objetivos estabelecidos em Tampere exemplifica-se pelo mandado de detenção europeu (MDE), estabelecido pela decisão-quadro 2002/584/ JAI do Conselho. ${ }^{44}$ No sentido de reforçar a confiança mútua e facilitar o processamento de pedidos de execução, foi criado o mandado de detenção europeu. Tinha como objetivo o fim dos procedimentos complexos. Com isso houve uma importante modificação no modo tradicional de cooperação entre os estados, trazendo consigo uma série de conseqüências práticas. O procedimento passa a se desenvolver diretamente entre as autoridades judiciais, criando um novo paradigma de cooperação. ${ }^{45} \mathrm{~A}$ intervenção de outras instâncias que não sejam apenas os magistrados envolvidos é dispensada.

Com o MDE deixou de existir para alguns crimes a necessidade de dupla incriminação. De acordo com este princípio, o reconhecimento de decisões judiciais na área penal deve pressupor que o ilícito seja considerado crime tanto pelo estado requerente, quanto pelo estado requerido. Esse princípio não mais se aplica a 32 tipos penais. ${ }^{46}$ A mitigação da dupla incriminação é vista com grande ceticismo por alguns

42 JO da União Européia C 83 de 30.03.2010, p. 389-403.

43 SCHWARZE Jürgen. EU-Kommentar. 2. ed. Baden-Baden: Nomos, 2009. p. 164.

44 JO das Comunidades Européias L 190 de 18.07.2002, p. 1-20.

45 FERREIRA, Joana; MARTINS, Teresa Alves. Mamual de procedimentos relativos à emissão do mandado de detenção europeu. Procuradoria Geral da República de Portugal. p. 7. Disponível em: <http://www.gddc. pt/MDE/Manua]_MDE.pdf>. Acesso em: 14 jun. 2010.

46 Participação em organização criminosa, terrorismo, tráfico de seres humanos, exploração sexual de crianças e pedofilia, pornografia,tráfico ilícito de estupefacientes e de substâncias psicotrópicas, tráfico ilícito de armas, munições e explosivos,corrupção, fraude, incluindo a fraude lesiva dos interesses financeiros das Comunidades Européias, branqueamento dos produtos do crime, falsificação de moeda, incluindo a contrafacção do euro, cibercriminalidade, crimes contra o ambiente, incluindo o tráfico ilícito de espécies animais ameaçadas e de espécies e essências vegetais ameaçadas, auxílio à entrada e à permanência irregulares, homicídio voluntário, ofensas corporais graves, tráfico ilícito de órgãos e de tecidos humanos, rapto, seqüestro e tomada de reféns, racismo e xenofobia, roubo organizado ou à mão armada, tráfico de bens culturais incluindo antiguidades e obras de arte, burla, extorsão de proteção e extorsão, contrafacção e piratagem de produtos, falsificação de documentos administrativos e respectivo tráfico, falsificação de meios de pagamento, tráfico ilícito de substâncias hormonais e outros fatores de crescimento, tráfico ilícito 
Estados-Membros, que têm demonstrado grande preocupação em ver seus cidadãos serem incriminados por ilícitos inexistentes em seu sistema.

Por outro lado, há quem sustente que o reconhecimento mútuo só se justifica na medida em que se estenda também a ilícitos tratados de maneira diferenciada pelos estados. ${ }^{47}$ De acordo com essa visão o mecanismo do mútuo reconhecimento estaria esvaziado se aplicado somente aos delitos com tratamento homogêneo entre os Estados-Membros, pois esses delitos homogêneos já seriam facilmente reconhecidos, por deterem características comuns. Dessa argumentação se conclui que um mandado de detenção europeu só faria sentido justamente nos crimes para os quais não se requer dupla incriminação, pois nos demais casos não haveria grandes dificuldades em se proceder ao reconhecimento de decisões.

A argumentação procede em parte. O reconhecimento mútuo tem por objetivo estimular e facilitar a aplicabilidade das decisões judiciais. Essa meta não se restringe somente aos ilícitos tratados de maneira heterogênea pelos estados, pois ao contrário do que se argumenta, nem sempre os ilícitos homogêneos eram facilmente reconhecidos. Não obstante a similitude de tipos penais em alguns Estados-Membros o processo de reconhecimento mútuo era bastante complicado. O MDE quis facilitar tanto a execução de sanções à lesão de bens que já eram protegidos de maneira semelhante, como de bens protegidos de formas diferentes. A garantia de execução das decisões em delitos tratados de maneira igualitária pode ser ainda mais importante, pois partem de princípios compartidos por todos os Estados-Membros. De forma que a instrumentalidade do MDE inclui além dos crimes nos quais não se exija a dupla incriminação, também aqueles em que ela é necessária. Ou seja, há uma dupla utilidade e não o esvaziamento pregado por alguns autores.

Mas a implementação do MDE sofreu ainda outros empecilhos. A legislação nacional alemã que incorporou o MDE foi reconhecida como nula pelo Tribunal Constitucional Alemão, por violação ao art. 16 da lei fundamental alemã ${ }^{48}$ que versa sobre cidadania e extradição. No caso, uma autoridade espanhola havia pedido a extradição de um cidadão alemão e sírio, por crimes de terrorismo e associação criminosa. Esse cidadão foi detido na cidade de Hamburgo e seu questionamento quanto à legalidade da prisão chegou até o Tribunal Constitucional Alemão. De acordo com a decisão, o cidadão tem o direito à certeza do direito a ele aplicável, tratando-se de uma questão de confiança. A

de materiais nucleares e radioativos, tráfico de veículos roubados, violação, fogo-posto, crimes abrangidos pela jurisdição do Tribunal Penal Internacional, desvio de avião ou navio e sabotagem.

47 Gallagher, Paul. Future Developments in Judicial Cooperation in Criminal Matters. Europäische Rechtsakademie, 2009. Disponivel em: <http://www.springerlink.com/content/5620881g73466768/>. Acesso em: 28 jan. 2010.

48 A decisão proferida em 18.07.2005. Disponivel em: <http://www.bundesverfassungsgericht.de/ entscheidungen/rs20050718_2bvr223604.html>. Acesso em: 04 jun. 2010. 
idéia é que o cidadão tenha o direito a não ser removido de um sistema no qual se sente seguro. E ainda: a extradição deveria ser proporcional. Na decisão o tribunal afirma que o reconhecimento mútuo não pode ser rígido a ponto de limitar a garantia constitucional dos direitos fundamentais. Por isso, enquanto não entrar em vigor nova lei sobre extradição, a extradição em que a Alemanha seja estado parte, terá como base a Convenção Européia de extradição de $1957 .{ }^{49}$

Aproximação da legislação penal

Talvez a aproximação legislativa seja a medida de prevenção e combate à criminalidade mais controvertida. Antes das mudanças introduzidas pelo Tratado de Lisboa, o art. 29, item 3 do TUE já previa "uma aproximação, quando necessário, das disposições de direito penal dos Estados-Membros nos termos do disposto na alinea e.) do artigo 31." A alínea e.) do artigo 31, por sua vez previa: "adoptar gradualmente medidas que prevejam regras mínimas quanto aos elementos constitutivos das infrações penais e as sanções aplicáveis nos dominios de criminalidade organizada, do terrorismo e do trafico ilicito de drogas." As aproximações legislativas eram feitas através das agora extintas, decisões-quadro, que vinculavam os Estados-Membros quanto ao resultado, de forma a não produziam efeito direto. Frise-se que a adoção de uma decisão-quadro dependia da unanimidade de votação no Conselho. Não tendo efeito direto, o teor das decisõesquadro inseria-se na ordem jurídica dos Estados-Membros mediante a manifestação dos parlamentos nacionais.

Com o Tratado de Lisboa a competência material para instituição de regras mínimas de direito penal tornou-se ainda maior. O art. 83 do TFUE prevê a adoção de diretivas para o estabelecimento de regras mínimas que definam as infrações e sanções penais nos crimes graves com dimensão transnacional.

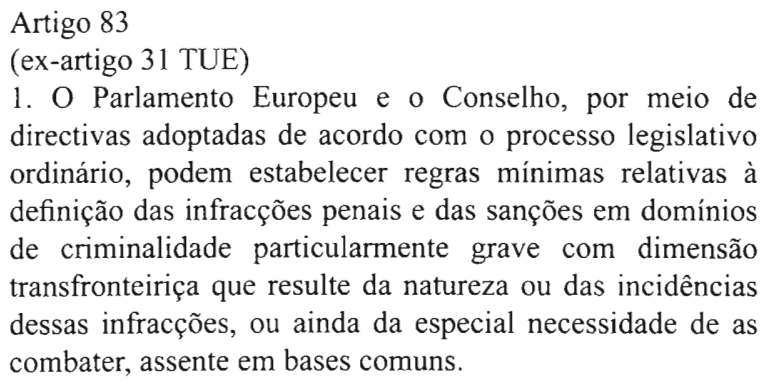

49 Disponível em: <http://conventions.coe.int/Treaty/EN/Treaties/Html/024.htm>. Acesso em: 04 jun. 2010. 
São os seguintes os domínios de criminalidade em causa: terrorismo, tráfico de seres humanos e exploração sexual de mulheres e crianças, tráfico de droga e de armas, branqueamento de capitais, corrupção, contrafacção de meios de pagamento, criminalidade informática e criminalidade organizada.

Consoante a evolução da criminalidade, o Conselho pode adoptar uma decisão que identifique outros domínios de criminalidade que preencham os critérios referidos no presente número. O Conselho delibera por unanimidade, após aprovação do Parlamento Europeu.

2. Sempre que a aproximação de disposições legislativas e regulamentares dos Estados-Membros em matéria penal se afigure indispensável para assegurar a execução eficaz de uma política da União num domínio que tenha sido objecto de medidas de harmonização, podem ser estabelecidas por meio de directivas regras mínimas relativas à definição das infracções penais e das sanções no domínio em causa. Essas directivas são adoptadas de acordo com um processo legislativ ordinário ou especial idêntico ao utilizado para a adopção das medidas de harmonização em causa, sem prejuízo do artigo 76 .

3. Quando um membro do Conselho considere que um projecto de directiva a que se refere o n. 1 ou n. 2 prejudica aspectos fundamentais do seu sistema de justiça penal, pode solicitar que esse projecto seja submetido ao Conselho Europeu. Nesse caso, fica suspenso o processo legislativo ordinário. Após debate, e havendo consenso, o Conselho Europeu, no prazo de quatro meses a contar da data da suspensão, remete o projecto ao Conselho, o qual porá fim à suspensão do processo legislativo ordinário.

No mesmo prazo, em caso de desacordo, e se pelo menos nove EstadosMembros pretenderem instituir uma cooperação reforçada com base no projecto de directiva em questão, esses Estados-Membros notificam o Parlamento Europeu, o Conselho e a Comissão em conformidade. Nesse caso, considera-se que foi concedida a autorização para proceder à cooperação reforçada referida no n. 2 do art. 20 do Tratado da União Européia e no n. 1 do art. 329 do presente Tratado, e aplicam-se as disposições relativas à cooperação reforçada

Para o TFUE agora as regras mínimas só podem incidir se o crime tiver (a.1) caráter transnacional e (a.2) se for grave ou se (b) houver necessidade especial de as combater em bases comuns. Portanto, o TFUE restringe, por um lado a competência material para aproximação legislativa, quando se refere a criminalidade grave com dimensão transnacional (algo que não era explicito antes da reforma), e por outro lado amplia a competência material ao permitir que sejam aproximadas legislações apenas com 
fundamento na necessidade de se combaterem ilícitos em bases comuns. A vagueza da previsão é criticada pelo Tribunal Constitucional Alemão em sua decisão sobre a adoção do Tratado de Lisboa pela Alemanha, ${ }^{50}$ e também criticada por Kai Ambos. ${ }^{51}$ Realmente a abertura deixada pela parte final do artigo permite possivelmente o excessivo alargamento das competências da União Européia, algo que não seria novo na história de seu desenvolvimento. O Tribunal Constitucional Alemão entendeu que uma possível decisão baseada na última parte do art. 83 só seria admitida com a manifestação da vontade dos órgãos europeus.

Em relação à primeira parte do art. 83 que prevê a adoção de regras mínimas que se refiram a crimes de grave dimensão transnacional, esses crimes são elencados a seguir como sendo: terrorismo, tráfico de seres humanos e exploração sexual de mulheres e crianças, tráfico de drogas e armas, branqueamento de capitais, corrupção, contrafação de meios de pagamento, criminalidade informática de criminalidade organizada. Esses domínios de criminalidade, sobre os quais pode incidir a instituição de regras mínimas, podem ser estendidos, conforme a evolução da criminalidade.

A incorporação de novos domínios a serem disciplinados por regras mínimas deve ser feita por votação unânime do Conselho. Novamente aparece aqui a exceção da intergovernabilidade, que aparece nos casos mais sensiveis de mecanismos de integração, principalmente em matéria penal. Esse cuidado é importante para evitar desconfianças por parte dos Estados-Membros e em alguns outros casos em que a regra do intergovernabilidade foi suprimida ela poderia ter tido um efeito mais benéfico de construção de confiança mútua entre os Estados-Membros.

Ainda em relação à harmonização legislativa o art. $82, \mathrm{n}^{\circ} 2$ do TFUE prevê a adoção de diretivas para o estabelecimento de regras mínimas. Essa aproximação só pode dar-se na medida em que seja necessária para facilitar o reconhecimento mútuo de decisões judiciais e a cooperação policial e judiciária nas matérias penais com dimensão transfronteiriça. A utilização do vocábulo necessário leva à conclusão de que somente será utilizada a aproximação legislativa, na medida em que não haja alternativa mais branda que produza o mesmo efeito. Aqui não se fala em custo do efeito ou eficiência, mas a mera possibilidade de se atingir o mesmo efeito já impossibilitaria em tese a aproximação legislativa.

As regras mínimas podem ter como objeto; (a) a admissibilidade mútua dos meios de prova, (b) os direitos individuais em processo penal, (c) os direitos das vítimas

50 Caso de Lisboa, BVerfG 2/08, de 30.06.2009. Disponível em: <http://www.bundesverfassungsgericht.de/ entscheidungen/es20090630_2bve000208.html >. Acesso em: 19 abr. 2010.

51 AMBOS, Kai. Erste Überlegung zu den Konsequenzen des Lissabon-Urteils des Bundesverfassungsgerichts fü das Europäische Strafrecht. Disponivel em: http://www.zis-online.com>. Acesso em: 17 jan. 2010. p. 401-403. 
da criminalidade e ainda (d) outros elementos específicos do processo penal. Sendo essa última previsão excessivamente genérica, o ato só será adotado por deliberação unânime do Conselho. A intergovernabilidade atua aqui como um freio a qualquer pretensão excessivamente expansiva, que não seja estritamente necessária.

Além da harmonização das disposições legislativas, é possível ainda que a UE estabeleça medidas de incentivo e apoio a ação dos Estados-Membros para prevenção da criminalidade. Essa criminalidade não é necessariamente transfronteiriça e por isso a possibilidade de harmonização é descartada, de acordo com o art. 84 do TFUE.

A aproximação legislativa também coloca em discussão como e em que medida interagem as normas comunitárias e as normas nacionais. Essa é uma questão nem sempre fácil de se resolver.

O caso Maria Pupino, ${ }^{52}$ no qual uma professora com esse nome foi acusada na Itália de agressão a seus alunos, é exemplificativo de como essa interação entre norma interna e comunitária deve ser analisada. No caso, as vítimas eram menores. Isso fez com que elas fossem ouvidas ainda na fase instrutória, por temor de que seus depoimentos sofressem distorções com o passar do tempo. Havendo desta forma produção antecipada de provas. Mas, a lei processual penal italiana só admitia a produção antecipada de provas em casos específicos, sendo que as circunstâncias do caso não se enquadravam em nenhuma das hipóteses admitidas pela lei nacional. Em razão disso, Maria Pupino pediu que a prova antecipada fosse desconsiderada. Por outro lado, a decisão-quadro 2001/220/ JHA previa que vítimas particularmente vulneráveis recebessem tratamento especial e adequado à sua situação. Diante deses fatos, a juíza do caso na Itália suscitou um envio prejudicial ao TJCE. O pedido dirigido ao TJCE era para que este interpretasse os art. 2, 3 e 8 da decisão-quadro 2001/220/JHA. O TJCE conclui que, a legislação da UE não estabelecia expressamente os casos de produção antecipada de provas, mas que tendo-se em conta o espírito e objetivo da decisão-quadro o caso enquadrava-se sim nas previsões que admitiam circunstâncias especiais para oitiva de vitimas e testemunhas. Assim, a lei italiana deveria ser interpretada em consonância com a lei comunitária tanto o quanto possível.

Estabeleceu-se, portanto um critério de orientação para os casos de dúvida sobre a interação adequada entre norma da UE e norma nacional. A norma nacional deve estar de acordo com a regra comunitária tanto quanto possível. Embora o caso tenha se desenvolvido antes da entrada em vigor do tratado de Lisboa, o raciocínio permanece

52 Caso C-105/03, Coletânea do Tribunal de Justiça das Comunidades Européias I-5285 julgado em 16.06.2005 pela grande câmara do TJCE. Acórdão. Disponível em: <http://eur-lex.europa.eu/LexUriServ/LexUriServ. do? uri=CELEX:62003J0105:EN:HTML>. Acesso em: 06 jun. 2010. 
válido, pois a tendência é que se aumentem cada vez mais os casos de inter-relação entre norma nacional e européia.

O papel do Tribunal de Justiça

Em 2009, com as alterações ocorridas na estrutura da União Européia e o fim da separação entre assuntos comunitários e da União Européia, o Tribunal da Justiça Europeu passou a ter uma competência mais abrangente em relação à cooperação penal. De acordo com o art. 267 do TFUE cabe ao Tribunal de Justiça da União Européia deve: "decidir, a título prejudicial: a.) sobre a interpretação de tratado; b.) sobre a validade e interpretação dos actos adoptados pelas instituições, órgãos ou organismos da União" Qualquer órgão jurisdicional do Estado-Membro pode enviar ao Tribunal a questão prejudicial que considere necessária ao julgamento, mas se a decisão não for suscetível de recurso o órgão é obrigado a submetê-la ao órgão judiciário da União Européia. A previsão não comporta mais exceções, aplicando-se a todos os Estados-Membros, independentemente de sua aceitação. Houve, portanto, uma significativa mudança, já que antes em matéria de cooperação penal os estados podiam não se submeter à jurisdição do TJUE ou torná-la meramente facultativa.

Com a ampliação da competência do TJUE, alguns estados expressaram o temor de que a UE se imiscuísse em assuntos internos, alargando a competência a ela atribuída. Tendo em vista os interesses nacionais, consubstanciou-se a previsão do art. 276 do TFUE que prevê:

\section{Artigo 276}

Noexercício das suas atribuições relativamente às disposições dos Capítulos 4 e 5 do Título $\mathrm{V}$ da Parte III, relativas ao espaço de liberdade, segurança e justiça, o Tribunal de Justiça da União Européia não é competente para fiscalizar a validade ou a proporcionalidade de operações efectuadas pelos serviços de polícia ou outros serviços responsáveis pela aplicação da lei num Estado-Membro, nem para decidir sobre o exercício das responsabilidades que incumbem aos Estados-Membros em matéria de manutenção da ordem pública e de garantia da segurança interna.

A redação mantém a garantia já prevista no antigo Tratado da União Européia (art. 35, n. 5). É uma forma de defesa dos Estados-Membros da tendência em se alargar cada vez mais o campo de competências da união, não só através dos tratados internacionais, mas pelas atividades dos próprios órgãos da União Européia, principalmente do Tribunal de Justiça. Essa propensão pode ser verificada na pratica durante os 58 anos de atuação do órgão jurisdicional europeu, cuja jurisprudência outorgou à UE competências não expressamente previstas nos tratado, por exemplo, em relação ao meio-ambiente. De 
acordo com o art. $10^{\circ}$ do protocolo de mediadas transitórias, a nova competência atribuída ao TJUE só será implementada cinco anos após a entrada em vigor do Tratado de Lisboa. A comissão não pode, portanto, durante esse prazo propor ações contra os Estados-Membros que não respeitem os atos que se refiram à cooperação em matéria penal.

Os limites da competência da União Européia para dispor sobre cooperação penal

A questão da legitimidade decisória

Com o Tratado de Lisboa as disposições normativas sobre assuntos de cooperação penal deixam de ser tomadas pelo consenso dos representantes do Conselho passando a se submeter à regra da supranacionalidade. A modificação desse procedimento trouxe consigo o questionamento acerca da legitimidade da União Européia para dispor a respeito de um tema tão sensível aos interesses nacionais. Anteriormente às mudanças introduzidas pelo Tratado de Lisboa, por não haver eficácia direta das decisões, o legislativo nacional necessariamente intervinha no processo de incorporação de normas. Isso já não ocorre à partir de dezembro de 2009. A comunitarização da matéria implica, portanto, na modificação do processo decisório e na maneira como essa norma pode entrar na ordem jurídica nacional (agora diretamente).

A resistência em se delegar a competência para dispor sobre cooperação penal a uma entidade supranacional é mais do que natural. No momento da história em que o monopólio da força e do poder punitivo deixa de ser privado e passa a ser de uso exclusivo do estado o direito penal passa a ser uma das expressões mais típicas da soberania nacional, pois nenhum outro estado ou indivíduo pode dispor sobre justiça punitiva, ou executá-la em território nacional. É para preservar a paz interna que o estado reserva para si a prerrogativa exclusiva de determinar o que é o direito penal. Sendo o direito penal ultima ratio e sendo que se aplica a esse ramo do direito o princípio da legalidade estrita, o papel do legislativo nacional é sobressalente, já que no estado democrático de direito o direito penal só é modificado mediante a vontade dos representantes do povo. É raro que se admita em um ordenamento nacional a modificação do direito penal, sem que se passe pelo poder legislativo. A competência nessa área é guardada com um rigor muito mais elevado que em outras áreas do direito. Se em outros ramos do direito, como o administrativo, ou o direito das obrigações, as modificações normativas podem se dar por outras vias em que o legislativo nacional não participe, ou tenha uma participação pequena, isso não é admitido no direito penal. Por isso é que a questão do déficit de legitimidade democrática vem suscitando severas criticas à comunitarização da cooperação penal.

Por outro lado, seria possível argumentar que o Parlamento Europeu passa a exercer esse papel de legitimação democrática de edição de normas como expressão da vontade popular, de forma que em matéria de cooperação penal o legislativo europeu teria 
a mesma função do legislativo nacional. É verdade também que o Parlamento Europeu vem absorvendo cada vez mais as características dos tradicionais legislativos nacionais. Tem-se atribuído um papel cada vez mais proeminente ao Parlamento Europeu. Se este é eleito pelos cidadãos europeus, não haveria que se falar em déficit democrático na edição de normas européias a respeito de cooperação penal, já que o novo procedimento para cooperação penal previsto no TFUE prevê considerável participação do Parlamento. Na realidade o problema de se atribuir a competência para dispor sobre cooperação penal ao organismo supranacional não gira em torno da falta de manifestação da vontade popular em dispor sobre o tema, pois o Parlamento Europeu exerce agora importante papel nesse processo. O problema se dá em função das limitações impostas ao número de parlamentares europeus originários de cada Estado-Membro.

Kai Ambos apresenta diversos argumentos no sentido de que realmente há uma ampliação excessiva e talvez perigosa da competência da União Européia para cooperação penal. ${ }^{53} \mathrm{O}$ Parlamento Europeu não seria representativo o suficiente dos interesses dos nacionais dos maiores Estados-Membros, já que a proporção parlamentar europeu/cidadão não é a mesma para todos os Estados-Membros. O Parlamento não passaria da representação dos estados, já que não haveria correspondência populacional. A garantia de um uso não indevido desse instrumento deveria ser assegurada por um parlamento representativo de todos os cidadãos europeus de forma igualitária e é por isso que se fala em déficit democrático.

A não-representação da maioria dos cidadãos é um problema não somente para a questão da cooperação penal, mas para todas as matérias sobre as quais a União Européia tenha competência. É um problema institucional, mas que ganha especial relevo em uma matéria na qual o papel do legislativo é tão proeminente e não pode ser afastado. Portanto, a atribuição da competência da cooperação penal ao ente supranacional não engendra um problema democrático em si, mas a configuração institucional existente, a qual será utilizada para tomada de decisões sobre a matéria, faz surgir esse problema da falta de legitimação democrática, que não será resolvida por se retirar a competência da UE, mas sim por uma mudança na configuração do Parlamento Europeu.

Ciente de que mudanças drásticas na configuração do Parlamento Europeu poderiam levar a um choque talvez insuperável no interior da UE, o Tratado de Lisboa buscou alternativas na tentativa de satisfazer as críticas quanto ao déficit na representatividade. Prevê um mecanismo de controle das decisões da União Européia acerca da cooperação penal, por parte dos parlamentos nacionais. O art. 69 do TFUE prevê que os parlamentos nacionais devem "velar pela observância do princípio da

53 AMBOS, Kai. Erste Überlegung zu den Konsequenzen des Lissabon-Uteils des Bundesverfassungsgerichts für das Europäische Strafrecht. Disponível em: <http://www.zis-online.com>. Acesso em: 17 jan. 2010. 
subsidiariedade, em conformidade com o Protocolo relativo à aplicação dos princípios da subsidiariedade e proporcionalidade" nas iniciativas legislativas que digam respeito à cooperação penal judicial e policial. Mas ainda que se tenha demonstrado uma certa vontade política em apaziguar a vontade de alguns estados, a previsão é vista como insuficiente por parte da doutrina e por parte do legislativo do Estados-Membros.

Princípios aplicáveis à delimitação da competência

Ainda que a legitimidade democrática da União Européia para dispor sobre cooperação penal seja bastante questionável, o TFUE, com o qual os Estados-Membros se comprometeram, prevê a competência partilhada entre a UE e os Estados-Membros em matéria de liberdade, segurança e justiça (art. $4^{\circ}, n^{\circ} 2$, alínea j, TFUE). O exercício e a delimitação dessa competência são regidos pelos princípios gerais enunciados no TFUE e TUE. Eles se aplicam portanto à cooperação penal, que está inserida no domínio do espaço de liberdade, segurança e justiça.

Os considerandos dos tratados são interpretados pelo Tribunal de Justiça Europeu como direito positivo. Nesse mesmo sentido Motta de Campos os considera imperativos. ${ }^{54}$ Portanto, a facilitação da livre circulação de pessoas, a garantia de segurança de seus povos e todos os demais objetivos enunciados no TUE e no TFUE são finalidades. Todas as ações da UE devem estar voltadas à satisfação desses objetivos. Para Stancanelli “as competências da União Européia são definidas não tanto - ou pelo menos não só - em função dos setores de intervenção, mas mais em função dos objetivos perseguidos" 55

$\mathrm{O}$ art. $5^{\circ}$, n. 1 do Tratado da União Européia estabelece: “A delimitação das competências da União rege-se pelo princípio da atribuição. O exercício das competências da União rege-se pelos princípios da subsidiariedade e da proporcionalidade." O princípio da atribuição, já era previsto explicitamente à partir do Tratado de Nice. Entende-se que a UE atua na medida em que assim estabeleçam os tratados, cabendo aos EstadosMembros a competência residual. Portanto, tudo que não seja atribuído à União Européia é competência dos Estados-Membros. Em matéria penal isso significa que a União Européia pode atuar dentro das previsões estabelecidas nos art. 82, que permite à UE, através do Parlamento e do Conselho, adotar medidas para:

a) Definir regras e procedimentos para assegurar o reconhecimento em toda a União de todas as formas de sentenças e decisões judiciais;

54 CAMPOS, João Motta de. Direito comunitário. Lisboa: Fundação Calouste Gulbenkian, 1997. v. 3 , p. 40.

ss STANCANELLI, Di Paolo. Le competenze dell'Unione Europea. In: COLUCCI, Michele; SICA, Salvatore. L'Unione Europea: principi - instituzioni - politiche - constituzione. Bologna: Zanichelli Editore, 2005. p. 17, tradução livre. 
b) Prevenir e resolver os conflitos de jurisdição entre os Estados-Membros;

c) Apoiar a formação de magistrados e de funcionários e agentes de justiça;

d) Facilitar a cooperação entre as autoridades judiciárias ou outras equivalentes dos Estados-Membros, no âmbito da investigação e do exercício da acção penal, bem como da execução de decisões.

São igualmente atribuições da União Européia as previstas no art. 83, que prevêem o estabelecimento de "regras mínimas relativas à definição das infracções penais e das sanções em domínios de criminalidade particularmente grave com dimensão transfronteiriça que resulte da natureza ou das incidências dessas infracções, ou ainda da especial necessidade de as combater, assente em bases comuns"

Portanto em matéria de cooperação judiciária penal as ações da União Européia devem estar em consonância com essas atribuições ora enumeradas. Qualquer outra medida que não esteja de acordo com essas disposições expressas é de competência dos Estados-Membros. Naturalmente existirão casos em que é evidente a competência da União ou dos Estados-Membros, mas também haverão casos em que esse limite é bastante tênue.

Esse conflito de competências pode ser exemplificado através do caso C-440/05 56 suscitado pela Comissão contra o Conselho da UE. Pediu-se a anulação de algumas disposições (art. $4^{\circ}$ e $6^{\circ}$ ) da decisão-quadro 2005/667/JHA. Essa decisão-quadro previa penalidades criminais para o caso de poluição originária de navios. A decisãoquadro tinha por fundamento os arts. 31 (1) e 34 (2) (b) do Tratado da União Européia, conforme redação anterior ao Tratado de Lisboa. ${ }^{57} \mathrm{O}$ TJUE entendeu que a decisão-quadro era nula, pois a medida tomada pelo Conselho, tendo por base o antigo TUE usurpava as competências da Comunidade Européia, uma vez que a competência para dispor sobre transportes era atribuída a esta, por meio do então art. 80 (2) do antigo TCE ${ }^{58}$ O TUE vigente à época não atribuía à UE a competência para dispor sobre políticas comuns de transportes e proteção ao meio ambiente. Nesse caso, portanto a conflito de competências dava-se não em relação à UE e um Estado-Membro, mas em relação à UE a comunidade Européia. Não obstante, restou claro pela decisão do tribunal, que um ente só pode atuar na medida da atribuição expressamente prevista nos tratados acordados pelos Estados-

\footnotetext{
56 A decisão proferida pela grande câmara em 27.10.2007. Disponível em: <http://eur-lex.europa.eu/ LexUriServ/LexUriServ.do?uri=CELEX:62005J0440:EN:HTML>. Acesso em: 01 jun. 2010.

57 Conforme a redação do JO da União Européia C 321 de 29.12.2006, p. 1-331.

58 Idem.
} 
membros. Assim, a competência é delimitada pelas atribuições expressamente previstas e acordadas nos tratados.

Os princípios da subsidiariedade (art. $5^{\circ}$, n. 3, TUE) e da proporcionalidade (art. $5^{\circ}$, n. 4 , TUE), por sua vez, estabelecem não a extensão da competência em si, mas os limites de seu exercício. O princípio da subsidiariedade funciona como mecanismo de balizamento entre a atuação da União Européia e a atuação dos Estados-Membros no caso em que isso gere algum tipo de conflito de interesses. As implicações do princípio da subsidiariedade são bem explicadas por Da Silva:

Por força da subsidiariedade, a intervenção comunitária
fica sujeita a dois requisitos, um de carácter negativo
visando avaliar a eficácia comparativa através de possiveis
indicadores quantitativos (insuficiência dos Estados
Membros para alcançar o objectivo) e outro positivo
(necessidade da intervenção comunitáriaemelhor capacidade
para, considerando a extensão e efeitos do objectivo a
atingir, prosseguir o objectivo). A melhor capacidade deve
ser comprovada casuisticamente na fundamentação do acto.
O carácter transnacional ou transfronteirico do objecto
a atingir e da acção necessária é exemplo da extensão ou
efeitos a ponderar. ${ }^{59}$

A subsidiariedade é, portanto, composta por dois elementos: negativo e positivo. O elemento negativo se refere à incapacidade dos estados de alcançarem suficientemente determinado objetivo por si só ou ainda que consigam - devido às decisões ou aos efeitos da ação considerada - o objetivo for mais bem alcançado a nível da União. O elemento positivo, por sua vez, se refere à necessidade da UE agir. Assim, ainda que a UE tenha competência para implementar medidas de cooperação penal, ela só poderá ser efetivada pela União se os Estados por sua livre atuação e por suas disposições internas não conseguirem atingir o nível de cooperação pretendido pela União. Entretanto, esse critério negativo é aberto. Pois, a delimitação do que os Estados podem ou não alcançar autonomamente depende da forma como o objetivo é formulado. ${ }^{60}$ Quanto ao critério positivo da subsidiariedade, é preciso ainda que a medida de cooperação penal a ser implementada pela União seja realmente efetiva no sentido de persecução dos objetivos, pois do contrário ela se torna desnecessária.

59 DA SILVA, José Daniel T. F. Integração, subsidiariedade e autonomias na união européia, Portugal e as regiões autônomas dos Açores e Madeira. 2008. Tese (Doutorado) - Faculdade de Direito, Universidade de Santiago de Compostela. p. 1.012. Disponivel em: <http://books.google.com.br/books?id=f9lXcG0il98C\& $\mathrm{pg}=\mathrm{PA} 718 \& \mathrm{dq}=$ subsidiariedade + tratado $+\mathrm{de}+\mathrm{lisboa} \& \mathrm{~cd}=\mathrm{l} \# \mathrm{v}=$ onepage $\& \mathrm{q}=$ subsidiariedade $\% 20$ tratado $\% 20$ de $\% 20$ lisboa\& $\mathrm{f}=$ true $>$. Acesso em: $02 \mathrm{fev} .2010$.

60 RICHTER, Thomas, Jahresabschlussprüfung und Prüfungsanforderungen in der Europäischen Union. Baden-Baden: Nomos, 2003. p. 229. 
Mesmo preenchido o critério da subsidiariedade, a UE deve ainda se orientar por um segundo princípio, qual seja o da proporcionalidade. De forma que o ato europeu deve ter em conta se a medida a ser implementada guarda a devida proporção com o efeito que se quer alcançar. É em relação a esse aspecto principalmente que vem se questionando as medidas européias de combate ao terrorismo. Foi a falta de proporcionalidade que levou o Tribunal Constitucional Alemão a anular a legislação nacional que incorporava o mandado de detenção europeu. ${ }^{61}$ Assim a proporcionalidade é um critério que está a orientar a atuação da UE para fins de fiscalização não apenas por parte do TJCE, mas também por outras entidades nacionais. Os objetivos da União Européia estão a orientar os dois princípios que regem o exercício de sua competência: subsidiariedade e proporcionalidade. Esses princípios também devem ser observados ao se estabelecerem os limites da cooperação penal.

É possível, porém, que os objetivos expressamente previstos nem sempre encontrem as correspondentes competências estabelecidas de maneira clara, de forma que aqueles ficam sem previsão para que possam ser efetivamente implementados. Nesse caso a União Européia passa a recorrer à teoria das competências implícitas, materializada no art. 352 do TFUE, que permite uma ampliação das ações do ente integracionista. A previsão já existia no antigo Tratado que Institui a Comunidade Européia (TCE), em seu então art. 308, mas aplicava-se somente aos domínios previstos nesse diploma, não se estendendo, portanto, à política externa e segurança comum e à cooperação penal - que eram disciplinadas pelo antigo Tratado da União Européia. O atual art. 352, n. 4 do TFUE ressalva o domínio da política externa e segurança comum em relação ao procedimento de extensão da atuação. A mesma ressalva não foi feita quanto à cooperação em matéria penal, de forma que é possível que se adotem atos nessa área tendo-se em conta as competências implícitas.

$\mathrm{O}$ apelo às competências implícitas deve ser feito de forma meramente subsidiária e não à priori. Na verdade, a função dessa norma é construir a adequada ligação entre competência prevista e poder atribuído. Ela apenas possibilita a implantação de objetivos do tratado já previstos anteriormente, e não de alteração de objetivos já existentes, ou criação de novos. ${ }^{62}$ Mas, para o Tribunal de Justiça da União Européia, a previsão é uma espécie de reserva de poderes. Isso pode ter sérias conseqüências, levando até à usurpação de competências na área penal, algo que deve ser evitado. O procedimento para extensão da atuação não foi alterado em relação às previsões anteriores. As ações realizadas conforme o art. 352 do TFUE devem ser propostas pela Comissão, aprovadas

\footnotetext{
$61 \quad$ Vide p. 22-23.

62 RICHTER, Thomas. Jahresabschlussprüfung und Prüfungsanforderungen in der Europäischen Union. Baden-Baden: Nomos, 2003. p. 219.
} 
pelo Parlamento e em seguida aprovadas por unanimidade pelo Conselho. Como forma de controle dessa extensão da atuação da UE, os parlamentos nacionais devem ser comunicados de atos que tenham como base o art. 352 do TFUE. O que realmente mudou foram as matérias passíveis de tal procedimento - incluindo-se a cooperaçãø penal - e a necessidade de comunicação aos parlamentos nacionais.

Se por um lado a teoria das competências implícitas permite uma interpretação extensiva dos objetivos, e portanto da competência da UE, por outro, o princípio da atribuição das competências impõe limites ao apelo indiscriminado do art. 352 do TFUE. $O$ art. $4^{\circ}$ n. 2, alínea j.) prevê que o espaço de liberdade, segurança e justiça é objeto de uma competência partilhada. Mas a terminologia utilizada é muito genérica, permitindo interpretações alargadas. A cooperação penal não está expressamente prevista como objeto da competência, pois se insere dentro desse espaço de liberdade, segurança e justiça, que pode ter seu conceito ampliado, incluindo muito mais do que uma cooperação penal. Não obstante a cooperação penal estar inserida dentro da competência compartilhada expressa de manutenção de um espaço de liberdade, segunança e justiça, o TFUE prevê a cooperação policial e judiciária e não a criação ou modiffrcação do direito penal. O objetivo por detrás será sempre o da cooperação. Deve se observar que qualquer tentativa de ir além da mera cooperação, implementando regras que tenham efeitos para além dos casos em que seja necessário para a cooperação, não estaria amparada pelo tratado, mesmo que a competência do art. $4^{\circ}$, n. $2^{\circ}$ alínea j.) se refira genericamente a um espaço de liberdade, segurança e justiça.

Outra proposta de limitação material

A delimitação da competência material da União, comø se viè, é feita através da leitura dos dispositivos do tratado constitutivo e dos objetivos da UE. Safferling ${ }^{63}$ faz uma proposta interessante para fins de delimitação de competências, que seria complementar às regras de delimitação já existentes. Para ele haveria que se distinguïr no âmbito pena'l três espécies de normas: uma referente às instituições européias, outra referente a objetivos da União Européia e uma terceira referente a valores sociais de cada Estado-Membro. Com essa divisão haveria um meio de normatização mais adequado a cada uma dessas normas. Assim, para a proteção das instituições européias o ideal seria a elaboração de um código penal europeu, que de forma sistematizada previsse as condiçães de aplicaçãa da norma penal européia, mas tão somente para proteção dos interesses da União. FFaria parte, portanto, desse rol de normas as previsões, por exemplo, acerca da Procuradoria

63 SAFFERLING, Christoph J.M. Europe as Transnational Law. A Criminal Law for Europe: Between National Heritage and Transnational Necessities. German Law Journal, v. 10, n. 10. Disponivel em: <http://www. germanlawjournal.com/index.php?pageID=11\&artID=1213>. Acesso em: 01 jun. 2010. 
Européia. Por sua vez, os objetivos da UE deveriam estar protegidos apenas por normas administrativas, de forma que se descriminalizassem algumas condutas, deixando o direito penal como última forma de proteção de bens jurídicos. Por fim, outros valores sociais que não digam diretamente respeito aos interesses financeiros da União deveriam ser normatizados tão somente pelo direito nacional. Com isso a União passaria a legislar em matéria penal apenas naqueles casos em que um interesse seu seja diretamente afetado.

A estrutura tripartite sugerida pelo autor seria um valioso instrumento de interpretação para que se delimitassem os limites da atuação da União, mas a solução administrativa sugerida para os casos de lesão aos objetivos da União seria contraria e enfraqueceria a idéia de cooperação penal. A mera sanção administrativa por lesão aos objetivos da União esvaziaria a idéia de atuação conjunta dos estados. Pois, garantir um espaço de liberdade, segurança e justiça é um objetivo previsto nos tratados constitutivos, mas que em última análise diz respeito à garantia de justiciabilidade e efetividade do sistema dos próprios Estados-Membros. Portanto, há uma inter-relação muito forte entre os valores sociais de cada Estado-Membro e os objetivos da UE. Delegar somente aos Estados-Membros a proteção de certos valores sociais não é algo almejado pelos integrantes da UE, em que pese as críticas do sistema que vem sendo implementado. Fazem-se, portanto, necessárias algumas disposições européias acerca da interação entre os valores sociais de cada Estado-Membro.

Assim, ao invés de uma estrutura tripartite o ideal seria uma estrutura bipartite, em que haveria uma nítida separação entre (1) interesses da União e (2) interesses dos Estados-Membros. O ideal seria a implantação de um código penal europeu, apenas em relação aos crimes de lesão à União. As duas estruturas: interesses financeiros da união, e interesse dos Estados-Membros contariam com seu mecanismo próprio de interação entre norma nacional e norma européia, que haveriam de coexistir em medidas diferentes em cada uma dessas duas divisões. A diferenciação entre cada lado da estrutura bipartite seria dada pelas normas de interação (entre sistema nacional e supranacional), que haveriam de ser especificamente adequadas ao grupo de bens jurídicos protegidos - interesses da união ou interesse dos Estados-Membros. Portanto - contrariando a tese de Safferling ${ }^{64}$ - ainda seriam possíveis normas européias sobre a cooperação entre os Estados-Membros, como é hoje, pois a normatização européia é necessária à efetiva cooperação.

64 SAFFERLING, Christoph J.M. Europe as Transnational Law. A Criminal Law for Europe: Between National Heritage and Transnational Necessities. German Law Journal, v. 10, n. 10. Disponível em: <http://www. germanlawjournal.com/index.php?pagelD=11\&artID=1213>. Acesso em: 01 jun. 2010. 


\section{Conclusão}

A cooperação penal deve ter como objetivo principal o melhoramento da prestação jurisdicional estatal, a eficácia no combate e prevenção ao crime e a efetiva execução das decisões. Longe de afastar a soberania estatal ela acaba por reforçá-la, na medida em que fortalece o sistema jurídico de cada país. Quando esses objetivos não são satisfeitos há que se rever se essa cooperação é realmente desejável.

Nesse diapasão a iniciativa européia tem encontrado maneiras de implementar uma integração da justiça criminal bastante interessantes. Claramente esse processo possui falhas sujeitas a inúmeras críticas. Os questionamentos, feitos pela doutrina, e até mesmo pelos Estados-Membros, são importantes para o processo de evolução do sistema de cooperação. O aprimoramento da cooperação penal, desde que ela se iniciou com o Tratado de Maastricht, é fruto em grande medida das críticas direcionadas à cooperação penal. Se no início ela sofria com a inoperacionalidade, agora ela vem sendo criticada pelo excessivo alargamento da competência material da UE.

As inovações trazidas pelo Tratado de Lisboa na área de cooperação penal introduziram um cenário bastante diferente ao anterior. Buscou-se dar maior dinamismo às decisões da UE a respeito do tema, ao permitir que atos sejam adotados mesmo sem a unanimidade de votos. Por outro lado, a questão do déficit democrático, que extrapola a matéria penal, é algo a se resolvido urgentemente, sob pena de se prejudicar todo o processo de integração, deslegitimando-o.

A previsão de uma Procuradoria Européia também foi um importante passo para uma efetiva proteção dos interesses da União, mas o possível alargamento da competência desse órgão para tratar de outros crimes transnacionais é algo a ser analisado com bastante cautela. Ter a persecução penal iniciada e desenvolvida por um ente supranacional é um grande passo. A implementação de um órgão dessa natureza e com tamanhos poderes implica a necessidade do estabelecimento de regras claras para sua atuação e fiscalização. No âmbito interno os órgãos responsáveis pela persecução penal levaram muitos anos para serem desenvolvidos como hoje existem. Os ministérios públicos de cada Estado-Membro têm sua atuação pautada na realidade de seu próprio país e por regras adequadas à realidade de cada lugar. $\mathrm{O}$ alargamento da competência da Procuradoria Européia deveria ter em conta os paradigmas de direito penal existentes em cada um dos Estados-Membros e talvez por isso mesmo esse objetivo de alargamento da competência não seja ideal.

Outra questão preocupante diz respeito à possibilidade de usurpação de competências por parte da UE. Esse fenômeno deve ser atentamente observado, pois uma cooperação é mais do que necessária e deve ser eficiente, célere, mas cooperação não deve ser confundida com a transferência das competências para dispor livremente sobre o direito penal dos Estados-Membros. Esse ainda é um domínio extremamente sensível. 
Por isso os critérios de delimitação de competência devem estar bastante claros e assentes. Embora a jurisprudência tenha um importante papel nesse sentido, fazem-se necessárias mais regras materiais para adequada delimitação das competências e menos vagueza das disposições atualmente existentes. Essa necessidade advém do fato de que o direito europeu é aplicado não apenas por instituições européias, mas também por instituições sociais dos Estados-Membros. É utilizado, por exemplo, pelos juízes em suas decisões, como no caso Maria Pupino e no caso de extradição que culminou na não aplicação do mandado de detenção europeu (MDE) na Alemanha.

São Paulo, dezembro de 2010.

Referências

Fontes Primárias

DIÁRIO OFICIAL DA UNIÃO. Convenção de Palermo das Nações Unidas contra o crime organizado transnacional. 15.11.2000, Decreto 5015 de 12.03.2004, de 15.03.2004.

DIÁRIO OFICIAL DA UNIÃO. Convenção interamericana sobre o cumprimento de sentenças penais no exterior. de 09.06.1993, Decreto 5919 de 03.10.2006, de 04.10.2006.

DIÁRIO OFICIAL DA UNIÃO. Convenção interamericana sobre trafico internacional de menores. de 18.04.1994, Decreto 2740 de 20.08.1998, de 20.08.1998.

JO DAS COMLNIDADES EUROPÉIAS. Decisão 2002/187/JAI do Conselho. L 63 de 06.3.2002. p. 1 .

JO DAS COMUNIDADES EUROPÉIAS. Decisão-quadro 2002/475/JAI do Conselho. L 164 de 22.6.2002. p. 3 .

JO DAS COMUNIDADES EUROPÉIAS. Decisão-quadro 2002/584/JAI do Conselho. L 190 de 18.07.2002. p. 1 .

JO DAS COMUNIDADES EUROPÉIAS. Decisão-quadro 2002/629/JAI do Conselho. L 203 de 1.8.2002. p. 1.

JO DA UNIÃO EUROPÉIA. Decisão-quadro 2003/568/JAI do Conselho. L 192 de 31.7.2003. p. 54.

JO DA UNIÃO EUROPÉIA. Decisão-quadro 2004/68/JAI do Conselho. L 13 de 20.1.2004. p. 44.

JO DA UNIÃO EUROPÉIA. Decisão-quadro 2004/757/JAI do Conselho. L 335 de 11.11.2004. p. 8. JO DA UNIÃO EUROPÉIA. Decisão-quadro 2004/757/JAI do Conselho. L 335 de 11.11.2004. p. 8. JO DAS COMUNIDADES EUROPÉIAS. Posição comum 97/783/JAI do Conselho. L 320 de 21.11.1997. p. 1. 
DIÁRIO OFICIAL DA UNIÃO. Protocolo de assistência jurídica mútua em assuntos penais do Mercosul. 25.06.1996, Decreto 3468 de 12.05.2000, de 18.05.2000.

JO DA UNIÃO EUROPÉlA. Regulamento do Conselho 1290, L 209/1, de 11.08.2005, p. 1.

JO DA UNIÃO EUROPÉIA. Regulamento do Conselho 1782 de 2003, L 270/1 de 21.10.2003, p. 1.

JO DA UNIÃO EUROPÉIA. Tratado da União Européia, versão compilada, C 115, de 09.05.2008, p. 13.

JO DA UNIÃO EUROPÉIA. Tratado da União Européia, versão compilada, C 321E, de 29.12.2006, p. 1.

JO DA UNIÃO EUROPÉIA. Tratado de Lisboa, de 13.12.2007, C 306, de 17.12.2007.

JO DA UNIÃO EUROPÉIA. Tratado que Institui a Comunidade Européia, versão compilada, C 321E, de 29.12.2006, p. 1.

JO DA UNIÃO EUROPÉIA. Tratado sobre o Funcionamento da União Européia versão compilada, C 115, de 09.05.2008, p. 47.

\section{Fontes Secundárias}

BOULOUIS, Jean. Droit institutionnel de L'Union Européenne. 5. e. Paris: Montchrestien, 1995.

CASELLA, Paulo Borba; SANCHEZ, Rodrigo Elian (Org.). Cooperação judiciária internacional. São Paulo: Renovar, 2002.

Elementos de direito comunitário. 1993. Tese (Livre-docência) Faculdade de Direito, Universidade de São Paulo, São Paulo.

Manual de direito internacional público. 16. ed. São Paulo: Saraiva, 2008.

CHEVALLIER-GOVERS, Constance. De la coopération à l'intégration policière dans l'Union Européenne. Bruxelles: Bruylant, 1999.

DA SILVA, José Daniel T. F. Integração, subsidiariedade e autonomias na União Européia, Portugal e as regiões autônomas dos Açores e Madeira. Tese (Doutorado) - Faculdade de Direito, Universidade de Santiago de Compostela. 2008. Disponível em: $<$ http://books.google.com.br/books ?id=f9lXcG0il98C\&pg=PA718\&dq=subsidiariedade + tratado + de + lisboa\& $\mathrm{cd}=1 \# \mathrm{v}=$ onepage $\& \mathrm{q}=$ su bsidiariedade $\% 20$ tratado $\% 20$ de $\% 20$ lisboa\&f=true $>$. Acesso em: 02 fev. 2010.

DAVIN, João. A criminalidade organizada transnacional. 2. ed. Coimbra: Almedina, 2007.

DI PAOLO, Stancanelli. Le competenze dell'Unione Europea. In: COLUCCI, Michele; SICA, Salvatore. L'Unione Europea: principi - instituzioni - politiche - constituzione. Bologna: Zanichelli Editore, 2005. 
FERREIRA, Joana; MARTINS ,Teresa Alves. Manual de procedimentos relativos à emissão do mandado de detenção europeu. Procuradoria Geral da República de Portugal, 2007. Disponível em: $<$ http://www.gddc.pt/MDE/Manual_MDE.pdf>. Acesso em: 14 jun. 2010.

FLETCHER, Maria. Police and Judicial Cooperation in Criminal Matters: Improving Governance. In: European Union Studies Association Bianual Conference 2005. Austin. Disponível em: <http:// aei.pitt.edu/3067/>. Acesso em: 04 fev. 2010.

GALLAGHER, Paul. Future Developments in Judicial Cooperation in Criminal Matters. Europäische Rechtsakademie. 2009. Disponível em: <http://www.springerlink.com/ content/5620881g73466768/>. Acesso em: 28 jan. 2010.

GAUTRON, Jean-Claude. Droit européen. 8. ed. Paris: Dalloz, 1997.

MÖLDERS, Simone. Case Note. The European Arrest Warrant in the German Federal Constitutional Court. German Law Journal, v. 7, n. 1. Disponível em: <http://www.germanlawjournal.com/article. php?id=685>. Acesso em: 04 maio 2010.

MOTA, José Luís Lopes da. A União Européia face à criminalidade transnacional: a caminho de um Ministério Público Europeu? Disponível em: <http://www.ieei.pt/files/Ministerio_Publico_ Europeu_Jose_Luis_Lopes_Mota.pdf $>$. Acesso em: 2 fev. 2010.

CAMPOS, João Motta de. Direito comunitário. Lisboa: Fundação Calouste Gulbenkian, 1997.

. Manual de direito comunitário. 4. ed. Lisboa: Fundação Calouste Gulbenkian, 2004.

MÜLLER-GRAFF, Peter-Cristian. Der Raum der Freiheit, der Sicherheit und des Rechts in der Lissabonner Reform. In: SCHWARZE, Jürgen; HATJE, Armin. Der Reformvertrag Von Lissabon. Baden-Baden: Nomos, 2009. p. 105-126.

MUSACCHIO, Vincenzo. Derecho penal econômico, criminalidad organizada y Union Europea. Revista Brasileira de Ciências Criminais, São Paulo, v. 14, n. 60, p. 208-220, maio/jun. 2006.

OCAMPO, Raúl Granillo. Direito internacional público da integração. Rio de Janeiro: Campus, 2009.

PISTOIA, Emanuela. Cooperazione penale nei rapporti fra diritto dell'Unione Europea e diritto statale. Napoli: Scientifiche Italiane, 2008.

RICHTER, Thomas. Jahresabschlussprüfung und Prüfungsanforderungen in der Europäischen Union. Baden-Baden: Nomos, 2003.

Normas internacionais de auditoria: esforços internacionais para sua elaboração e sua eventual adoção pelo direito europeu. Revista Brasileira de Contabilidade, Brasília, n. 158, p. 8797, mar./abr. 2006.

SAFFERLING, Christoph J. M. Europe as Transnational Law. A Criminal Law for Europe: Between National Heritage and Trnasnational Necessities. German Law Journal, v. 10, n. 10. Disponível 
em: $<$ http://www.germanlawjournal.com/index.php?pageID=11\&artID=1213>. Acesso em: 01 jun. 2010 .

SATZGER, Helmut. Internationales und Europäisches Strafrecht. 3. ed. Baden-Baden: Nomos, 2009.

SCHWARZE, Jürgen. EU-Kommentar. 2. ed. Baden-Baden: Nomos, 2009.

SIRACURA, Licia. Verso la comunitarizzazione della potestà normativa penale: un nuovo tassello della Corte di Giustizia dell'Unione Europea. Rivista Italiana di Diritto e Procedura Penale, Milano, v. 51, n. 1, p. 241-275, genn./mar. 2008.

Sousa, Alfredo José de. A criminalidade transnacional na União Européia. Um ministério público europeu? Coimbra:, Almedina, 2005.

SOUSA, Constança Urbano de. O novo terceiro pilar na União Européia: a cooperação policial e judiciária em matéria penal. In: DIAS, Jorge de Figueiredo (Org.). Estudos em homenagem a Cunha Rodrigues. Coimbra: Coimbra editora, 2001. p. 867-912.

SPIEZIA, Filippo. Crimini Transnazionale e Procedure di Cooperazione Giudiziaria. Milano: Il Sole, 2006.

STEINZ, Rudolph. Europarecht. Heidelberg: C. F. Müller Verlag, 2005.

TOFFOLI, José Dias. Mecanismos de cooperação jurídica internacional no Brasil. In: MINISTÉRIO DA JUSTIÇA. Manual de cooperação jurídica internacional e recuperação de ativos. Brasília: 2008 .

WEATHERILL, Stephen. Law and Integration in the European Union. New York: Oxford University Press, 1995. 